This item was submitted to Loughborough's Research Repository by the author.

Items in Figshare are protected by copyright, with all rights reserved, unless otherwise indicated.

\title{
PassivBIM: enhancing interoperability between BIM and low energy design software
}

PLEASE CITE THE PUBLISHED VERSION

http://dx.doi.org/10.1016/j.autcon.2015.04.014

PUBLISHER

(C) Elsevier B.V.

VERSION

AM (Accepted Manuscript)

\section{PUBLISHER STATEMENT}

This work is made available according to the conditions of the Creative Commons Attribution-NonCommercialNoDerivatives 4.0 International (CC BY-NC-ND 4.0) licence. Full details of this licence are available at: https://creativecommons.org/licenses/by-nc-nd/4.0/

\section{LICENCE}

CC BY-NC-ND 4.0

\section{REPOSITORY RECORD}

Cemesova, Alexandra, Christina Hopfe, and Rob McLeod. 2015. "Passivbim: Enhancing Interoperability Between BIM and Low Energy Design Software". Loughborough University. https://hdl.handle.net/2134/18288. 


\title{
PassivBIM: Enhancing interoperability between BIM and low energy design software
}

\author{
Alexandra Cemesova ${ }^{1 *}$, Christina. J. Hopfe ${ }^{2}$ and Robert S. McLeod ${ }^{3}$ \\ ${ }^{1}$ Institut National de l’Energie Solaire, 60 Avenue du Lac Léman, F-73375 Le Bourget du Lac, France \\ ${ }^{2}$ School of Civil and Building Engineering, Loughborough University, Loughborough, Leicestershire, LE11 \\ 3TU, UK \\ ${ }^{3}$ Building Research Establishment
}

*Corresponding author: Email: sasacemesova@gmail.com; Phone: +33648595409

\begin{abstract}
$\underline{\text { ABSTRACT }}$
The process of building design is currently undergoing some major changes. In an attempt to mitigate climate change, the design of more sustainable building is advocated by the UK government. Furthermore, standalone design methods are being replaced with the concept of Building Information Modelling (BIM). The adoption of BIM has been documented to result in many benefits, which range from time to cost savings. During the initial planning stages, building performance simulation (BPS) can be used to inform design decisions. Data can be exchanged between BIM and BPS tools using data transfer schemas such as the Industry Foundation Classes (IFC). The IFC schema lacks an energy domain, and as a result, an extension is proposed in this paper. This contains energy concepts from a BPS tool called Passive House Planning Package (PHPP). The extended schema was developed by way of an externally coupled Java tool, which facilitates the transfer of data, and informs the building design decision-making process. The process of geometry extraction has been validated with several case studies, which are based on certified Passivhaus buildings in Hannover Kronsberg, Germany and Ebbw Vale, Wales. The amount of error is acceptable, and it is mostly due to differences in the initial BIM model set up, not due to the processing of IFC files.
\end{abstract}

\section{INTRODUCTION}

Climate change is inevitable, and has been mainly caused by anthropogenic greenhouse gases [1]. Buildings are responsible for $40 \%$ of the final energy used globally [2]. In an attempt to mitigate climate change, the UK has bound itself to reducing its emissions by at least $80 \%$ by 2050, relative to the 1990 baseline [3]. In order to achieve this target, future buildings will have to become significantly more energy efficient [4]. This is supported by government environmental policies which calls for all new homes and schools, public sector buildings and potentially all new buildings to be zero carbon (or nearly zero energy) by 2016, 2019 and 2021 respectively [4][5][6]. The process of design is also evolving, from paper based and stand-alone Computer Assisted Design (CAD) methods to Building Information Modelling (BIM). The UK government supports these evolutionary changes, and has demanded that all Government Construction Strategy (GCS) projects are collaborative 3D BIM compliant by 2016 [7]. This means that all project and asset information, documentation and data are to be held in an electronic form, with some data exchange occurring.

The use of BIM provides many benefits associated with a common information model, which can range from cost to time savings as well as a reduced risk of design collisions and errors [8]. It can also be used throughout a projects lifecycle by the design team, owner, contractor and facility manager as part of ongoing monitoring, maintenance and refurbishment programmes [9]. As part of the BIM process, BIM authoring tools are used to plan an initial building design concept. This initial design is then iteratively refined in subsequent design stages based on an analysis of its performance using 'downstream' applications. The downstream applications can also be used for purposes such as to check compliance with building regulations [10], or to support a certification process. An example of the latter is the Excel-based low energy design tool Passive House Planning Package (PHPP). Use of this tool is a mandatory part of the design and certification process of producing a building which complies with the Passivhaus standard [11].

The Passivhaus standard is a fastest growing low energy standard in the world [4] [12] with over 50000 buildings completed worldwide [12], and over 270 certified buildings in the UK [13] [4]. It relies upon established low energy design principles such as passive solar design, high air tightness and high levels of insulation (e.g. triple glazing for windows). Ultra-low energy designs are becoming increasingly important, as the UK plans to reduce its emissions according to the Climate Change Act 2008 [3] and control buildings energy efficiency via standards such as the Fabric Energy Efficiency Standard (FEES)[14] [4]. PHPP uses quasi-steady state (monthly) energy balance calculations, which are based upon the international standard EN13790. In addition it is commonly used for other design and system sizing applications, such as the ventilation system design, sizing of the domestic hot water system, window specification design and the prediction of summer overheating risk [15] [16]. As a result, the tool can be used throughout the design process. PHPP has been proven to be accurate in comparisons with real measured data [17] and predictive results from dynamic tools [18][19].

Interoperability between BIM tools and PHPP is currently very low. Its MsExcel spreadsheet format may limit how it can be paired with BIM tools. There are however two main plug-ins available recently. The first is in the form of a SketchUp plug-in called 'designPH'. It enables data transfer to the 'Areas', 'Windows', 'Shading', and 'Components' sections of PHPP [20]. It transfers data using a heuristic algorithm to infer element types, temperature zones and area groups, in a file format developed by 
the PHI called ' $P P P$ '. No more information is given at the time of writing about the transfer process, or the file type. The other plug-in is called 'ph-tool'[21]. This is a Revit plug-in, which transfers data about quantities, dimensions, orientations and area. There is no more information publically available on how the data is actually transferred. Furthermore, it only works for Revit Architecture 2012 and 2013, and the Autodesk Building Design Suite 2013.

Other efforts include 'workarounds' [22], [23] and a proprietary solution from ArchiCAD. Duncan [22] focuses on exporting wall schedules from a BIM tool to PHPP, and [23] includes a few more building elements. These are all incomplete solutions as they only focus on exporting a section of information needed for an energy analysis. They are also time consuming, and prone to human error. It must be noted that ArchiCAD cannot currently be relied on for PHPP export. Although version 15 has the ability to export some details to PHPP, it appears that version 16 does not have this option [24]. However, a tool currently in the beta testing stage called EcoDesigner Star (part of the ArchiCAD 17 platform) includes an export to PHPP.

In order to avoid data repetition and redundancy, data can be transferred between BIM authoring tools and downstream applications using data transfer schemas. The Industry Foundation Classes (IFC) [25] is a data transfer schema that can describe the whole building lifecycle. A key limitation of this schema is that it does not include a description of an energy domain in the main specification. Research on an extension is described by O’Donnell et al. [26]. Its purpose is to support data exchange between HVAC design applications and energy analysis applications. It would not be suitable for data exchange between BIM and PHPP. An algorithm was also proposed by Rose and Bazjanac [27], which generates space boundaries for building simulation tools from IFC descriptions of buildings. Although this is an important advance in the field, it is not necessarily compatible with the PHPP calculation method of building element areas and more specifically the 'treated floor area' (TFA). There are many rules to verify if a space floor area can be added to the overall TFA, and building element areas are based on external dimensions of the building envelope. For example, the wall area may include the ground floor depth.To the authors' knowledge, there is no published research supporting interaction between IFC and PHPP.

This paper proposes a system called PassivBIM, whose purpose is to compile geometric and building fabric data from BIM authoring tools and to couple this with energy related information from PHPP. By combining this information in an independent Java based environment, energy performance calculations may be processed and post processed, opening up the possibility for rapid design optimisation routines. A similar IFC compliant tool which generates partial input data has been proposed by Gupta et al [29], but it's aim is to facilitate PV design. In addition, PassivBIM facilitates the automated transfer of data from a BIM tool to PHPP, thus providing a robust and time saving method of data entry for the purposes of Passivhaus design and certification. The methodology is validated using existing certified Passivhaus buildings in two locations. The first study focuses on buildings from the Hannover Kronsberg project [30]. The second is a detached house in Wales called Larch House. One of the main challenges in implementing the PassivBIM system was the extraction and processing of geometrical data from an IFC file. The resulting objectoriented building design tool PassivBIM can process input from IFC files, PHPP and user input. The IFC files are generated with a BIM tool called Autodesk Revit Architecture [31]. IFC input has been identified as an important user requirement in the past, along with the opportunity to model design alternatives [32]. This ability to store multiple design alternatives in the same IFC file will therefore be addressed by the PassivBIM IFC extension. PassivBIM creates a link between BIM-based tools and PHPP, as well as having the potential to perform independent third party optimization routines, which can inform users of optimised design possibilities.

The next section contains a brief overview of the interoperability between BIM and energy tools. This is followed by an overview of the geometrical data needed for the PHPP heating energy demand calculation. The PassivBIM methodology is then described in more detail. The case studies used are then detailed. Finally, the importance of the results is discussed and conclusions are drawn upon the PassivBIM tool.

\section{SUMMARY OF BIM AND ENERGY SIMULATION}

Current practice in the energy domain involves an architect designing a building and an energy specialist manually recreating it in a building energy model (BEM) analysis tool, and adding missing materials data such as thermal transfer coefficients (or Uvalues) [33]. Automating data exchange can enhance this process, resulting in: savings in time, a reduction in modelling errors whilst providing a synchronised and reproducible model. Exchanging building data often relies upon changing between model views of a building so data can be analysed by different domains. In the energy domain, an 'architectural view' is often transformed into a 'thermal view' [33], [34]. Such transformation is necessary for various reasons. For example, software tools are often standalone with different ways to represent a model, and concepts need to be mapped from one to another.

BIM is a good candidate as a base from which data could be extracted to different domains [35], such as daylighting or energy [36]. BIM is also an opportunity to hold data centrally, thereby avoiding data redundancy and repetition. Designers could improve their building iteratively as changes to a building would influence for example energy demand in real time. However, research into the interoperability of BIM and BPS tools reveals many, as yet unresolved, issues[26], [37], [38]. These indicate that data is often transferred using the IFC schema and the gbXML schema. The advantage of the gbXML schema is that it is supported by many BIM and energy tools [38]. However, the IFC schema has been identified as the "only public, non-proprietary and well developed data model for buildings and architecture existing today" [39]. It has a wider scope than gbXML, which is seen as an important factor[40]. 
Previous research has identified six stages of an ideal workflow from BIM to energy tools[41, p. 36]. These stages are: (1) defining the location of the building so it can be linked with weather data; (2) defining the geometry, constructions and materials and space types of a building; (3) assigning spaces as thermal zones; (4) assigning occupant, appliance and lighting loads to spaces; (5) defining in detail the HVAC system and its components; (6) running an energy simulation. The PassivBIM system focuses on developing the second stage in the transfer from a BIM tool to PHPP. This stage is an active research area [42], with early efforts including the creation of data schemas such as COMBINE [43]. Lawrence Berkeley National Laboratory (LBNL) has developed several IFC transformation utilities, such as the 'Space Boundary Tool', formally known as the 'Geometry Simplification Tool' [33], which translates geometry from IFC compatible CAD tools to EnergyPlus input data files (IDF) [44]. BIM to energy simulation is also the topic of ASHRAE research project 1468. A reference BIM model was developed for energy simulation, and presented in a seminar at the ASHRAE 2013 Winter Conference, but no published work is currently available on this project. It has however been noted that the thermal properties of building elements can deteriorate over time [45], which would indicate that an archived reference model would not necessarily be reliable for the subsequent energy simulations of existing buildings. A method is however proposed by Ham and Golparvar-Fard [45] using thermal imagery, which would enable reference models to have their thermal properties updated.

Transforming model geometry usually involves some degree of pre-processing and post-processing [40]. Pre-processing involves preparing raw data from a BIM tool, such as deleting elements or connecting surfaces and spaces using logic. Post-processing involves mapping data between the IFC format and the simulation tool. The PassivBIM project relies on both processing types. PHPP is quite different to most BPS tools, for example, it is spreadsheet-based and assumes there is only one thermal zone. It is to be expected that challenges in transforming geometric data to this tool will differ to the challenges presented for other energy tools, as discussed in a number of studies [37], [46]. For example, automatically determining wall placements can result in gaps occurring in thermal models, but a PHPP model uses external dimensions to define areas thus the process is more explicit. The next section contains details on the specific areas that PHPP references.

\section{PHPP - BALANCE BOUNDARIES AND GEOMETRY REQUIREMENTS}

PassivBIM replicates the calculations for the heating demand sections of PHPP. This involves balancing internal and solar gains with transmission and ventilation heat loss in accordance with the heat balance methods set out in EN 13790 [47]. Since PHPP defines the 'balance boundary' for these calculations in accordance with the external dimensions of the thermal envelope [47], the corresponding external areas of every thermal element must first be extracted from the BIM file. In order to calculate these, the area of the following components has to be calculated in square meters:

- Exterior walls (facing ambient air and the ground). The external face of an ambient wall is used as a starting point, and it is then adapted. If the main roof insulation is located above the uppermost ceiling and not in the roof rafters (i.e. cold roof construction), only the area of the wall face up to the height of the top of the insulation counts towards the external wall area. In addition, if there is an air gap (or ventilated cavity) between the external cladding and the wall through which air can flow, the cladding beyond this layer is not included as part of the external wall area. Ground facing (basement and below grade) walls are not currently handled by PassivBIM, and so will not be discussed here.

- $\quad$ Treated Floor Area (TFA). The treated floor area is the reference floor area inside the thermal envelope. The TFA must be accurately calculated as it forms the denominator to which all of the energy performance outputs in PHPP are normalised. For residential buildings it is calculated in accordance with guidelines presented in the German living space ordinance (WofIV) and for non-residential buildings it is based on the German norm DIN 277 [47]. There are many rules and conventions used in its calculation, most of which are described in the PHPP manual [47] and in further detail by Hopfe and McLeod [48]. A revised version of this document is currently in progress.

- Windows and external doors. These are calculated by multiplying the total height and widths of the external frame dimensions. The window areas also need to be associated with an orientation or azimuth $(\Phi)$, with respect to the deviation from North which the window faces (degrees) and the angle of inclination $(\theta)$ which is subtended by the zenith and the normal at the outer surface of the window (degrees) [47].

- Roof/ceiling. As with the external wall, the location of the roof/ceiling insulation has an impact on the determination of the roof area. If the insulation is located in plane with the highest ceiling, then the ceiling area is used as the roof area (for heat loss purposes). If the insulation is located in plane with the rafters, the actual roof area is calculated based on external area of the roof panels. The thickness of the external walls is included in the roof area but any overhangs must be removed, as they are not considered as part of the thermal envelope.

- $\quad$ Floor slab. The floor slab area is the area of the lowest floor, and it includes the footprint of the external walls.

In addition to the area, orientation and inclination of each thermal component, details regarding the material properties of the component are also required in order to determine the respective elemental energy balances. The thermal transfer coefficients (Uvalues) of each external component are currently calculated in the 'U-values' worksheet in the PHPP model, in accordance with EN6946, however it is conceivable that this information could be generated directly from the materials data stored in the IFC. Similarly linear and point thermal bridges in PHPP are generally calculated by additional two dimensional (or three dimensional) heat flow calculation programs [15]. Whilst thermal bridge lengths could be readily derived from the IFC files exported from BIM 
tools, substantial post processing of the basic IFC geometry would be required to prepare accurate 2D and 3D heat flux models compliant with the guidelines set out in EN10211.

Table 1 is a summary of the exchange requirements for the annual heat demand worksheet in PHPP, which is based on ISO 13790. The format of the table is the same as that used to define the exchange requirements by the BLIS Consortium [49]. Similar concepts will be found in most building energy simulation tools that adhere to the ISO 13790 calculation method. This highlights the pertinence of the IFC extension, proposed in later sections, to other simulation tools. The complete extension will however contain more pre-processing concepts then are mentioned here. For example, a connecting relationship is proposed between walls and windows to enable surface area subtraction, as well as concepts to ensure properties are not stored as a generic decimal number, but rather use a data type with appropriate units. The concepts in Table 1 will influence the development of the proposed extension, although the object names may change in order to ensure maximum consistency with pre-existing concepts in the IFC schema.

Table 1 The exchange requirements of PHPP's “Annual Heating Demand” worksheet.

\begin{tabular}{|c|c|c|c|c|c|}
\hline $\begin{array}{l}\text { Type of } \\
\text { information }\end{array}$ & Information needed & Required & Optional & Data type & Units \\
\hline \multirow{5}{*}{ Building Element } & Temperature zone & $\mathrm{x}$ & & String & $\mathrm{n} / \mathrm{a}$ \\
\hline & Area & $\mathrm{x}$ & & Real & $\mathrm{m}^{2}$ \\
\hline & U-Value & $\mathrm{x}$ & & Real & $\mathrm{W} / \mathrm{m}^{2} \mathrm{~K}$ \\
\hline & Temp. Factor & $\mathrm{x}$ & & Real & ${ }^{\circ} \mathrm{C}$ \\
\hline & Individual transmission heat loss & $\mathrm{x}$ & & Real & kWh/a \\
\hline \multirow[t]{5}{*}{ Window } & Orientation & $\mathrm{x}$ & & String & $\mathrm{n} / \mathrm{a}$ \\
\hline & Reduction Factor & $\mathrm{x}$ & & Real & $\mathrm{n} / \mathrm{a}$ \\
\hline & G-Value & $\mathrm{x}$ & & Real & $\mathrm{n} / \mathrm{a}$ \\
\hline & Area & $\mathrm{x}$ & & Real & $\mathrm{m}^{2}$ \\
\hline & Radiation & $\mathrm{x}$ & & Real & $\mathrm{kWh} / \mathrm{m}^{2} \mathrm{a}$ \\
\hline \multirow[t]{2}{*}{ Climate } & Gt (Heating Degree Hours) & $\mathrm{x}$ & & Real & $\mathrm{kKh} / \mathrm{a}$ \\
\hline & Ht (Length of heating period) & $\mathrm{x}$ & & Real & $\mathrm{d} / \mathrm{a}$ \\
\hline \multirow[t]{6}{*}{ Building } & Treated floor area & $\mathrm{x}$ & & Real & $\mathrm{m}^{2}$ \\
\hline & Climate & $\mathrm{x}$ & & String & $\mathrm{n} / \mathrm{a}$ \\
\hline & Building name & & $\mathrm{x}$ & String & $\mathrm{n} / \mathrm{a}$ \\
\hline & Location & & $\mathrm{x}$ & String & $\mathrm{n} / \mathrm{a}$ \\
\hline & Interior temperature & $\mathrm{x}$ & & Real & ${ }^{\circ} \mathrm{C}$ \\
\hline & Clear room height & $\mathrm{x}$ & & Real & $\mathrm{m}$ \\
\hline \multirow[t]{7}{*}{ Ventilation system } & Effective efficiency of heat recovery system & $\mathrm{x}$ & & Real & $\%$ \\
\hline & Efficiency of subsoil heat exchanger & $\mathrm{x}$ & & Real & $\%$ \\
\hline & Energetically Effective air exchange & $\mathrm{x}$ & & Real & $\mathrm{h}^{-1}$ \\
\hline & Mechanical air change rate $\left(\mathrm{n}_{\mathrm{v}}\right.$ System) & $\mathrm{x}$ & & Real & $\mathrm{h}^{-1}$ \\
\hline & Infiltration $\left(\mathrm{n}_{\mathrm{v}} \mathrm{Res}\right)$ & $\mathrm{x}$ & & Real & $\mathrm{h}^{-1}$ \\
\hline & Effective air volume & $\mathrm{x}$ & & Real & $\mathrm{m}^{3}$ \\
\hline & Volumetric specific heat capacity (air) & $\mathrm{x}$ & & Real & $\mathrm{Wh} / \mathrm{m}^{3} \mathrm{~K}$ \\
\hline \multirow{2}{*}{ Heat loss } & Total transmission heat loss & $\mathrm{x}$ & & Real & $\mathrm{kWh} / \mathrm{m}^{2} \mathrm{a}$ \\
\hline & Total ventilation heat loss & $\mathrm{x}$ & & Real & $\mathrm{kWh} / \mathrm{m}^{2} \mathrm{a}$ \\
\hline \multirow[t]{7}{*}{ Heat gain } & Power to energy time step conversion & $\mathrm{x}$ & & Real & $\mathrm{Kh} / \mathrm{d}$ \\
\hline & Specific Internal heat gain & $\mathrm{x}$ & & Real & $\mathrm{W} / \mathrm{m}^{2}$ \\
\hline & Total solar heat gain & $\mathrm{x}$ & & Real & $\mathrm{kWh} / \mathrm{m}^{2} \mathrm{a}$ \\
\hline & Total internal heat gain & $\mathrm{x}$ & & Real & $\mathrm{kWh} / \mathrm{m}^{2} \mathrm{a}$ \\
\hline & Utilisation factor & $\mathrm{x}$ & & Real & $\%$ \\
\hline & Free heat & $\mathrm{x}$ & & Real & $\mathrm{kWh} / \mathrm{m}^{2} \mathrm{a}$ \\
\hline & Ratio of free heat to losses & $\mathrm{x}$ & & Real & $\mathrm{kWh} / \mathrm{m}^{2} \mathrm{a}$ \\
\hline \multirow{4}{*}{$\begin{array}{l}\text { Annual heat } \\
\text { demand }\end{array}$} & Total annual heat demand & $\mathrm{x}$ & & Real & $\mathrm{kWh} / \mathrm{m}^{2} \mathrm{a}$ \\
\hline & Total heat loss & $\mathrm{x}$ & & Real & $\mathrm{kWh} / \mathrm{m}^{2} \mathrm{a}$ \\
\hline & Total heat gain & $\mathrm{x}$ & & Real & $\mathrm{kWh} / \mathrm{m}^{2} \mathrm{a}$ \\
\hline & PH Limiting value & $\mathrm{x}$ & & Real & $\mathrm{kWh} / \mathrm{m}^{2} \mathrm{a}$ \\
\hline
\end{tabular}

The following section details how the geometry in an IFC file has to be processed and adjusted so that it is suitable for PHPP calculations. 


\section{PROCESSING OF IFC GEOMETRY}

The main areas that have to be addressed are the construction elements which make up the external thermal envelope (walls, floor, roof, doors and windows) as well as the TFA to which all of the energy performance criteria are normalised (for comparative purposes). In this section, many points have to be transformed from the local coordinate system to the world coordinate system, or vice versa. This transformation was based on multiplying coordinates by transformation matrixes, whose derivation is described in more detail by Foley et al [50].

\subsection{Processing wall geometry}

The IFC can be used to describe two different types of walls: 'IfcWall' and 'IfcWallStandardCase'. According to Solihin the latter allows " more intelligent data to be exchanged" [51] as the 'I $f c$ Wall' is not associated with as much parametric data. As a result, only the 'IfcWallStandardCase' is currently supported by PassivBIM.

In the process of defining the thermal envelope, the first stage is to distinguish if a wall is external or not. This can be decided using the existing property set called 'Pset_WallCommon'. This property set has an attribute 'IsExternal' which can be true or false. Walls and property sets are connected using the relationship 'IfcRelDefinesByProperties'.

The next stage is to characterise the orientation of the wall. The orientation of windows is required by the solar heat gain calculation (as described in Section 3) but it is difficult to determine directly as windows can be described by a plethora of objects. The standard wall is described as a single object that is extruded and possibly voided and clipped. The wall orientation is therefore calculated instead, and then applied to windows that are embedded in it. A common convention is assumed for this process (after examining several IFC files): wall materials are described from the internal to the external face. The list of wall materials is an attribute of the entity 'IfcMaterialLayerSet'. This entity itself would be alluded to by an 'IfcMaterialLayerSetUsage', which is related to objects using the relationship 'IfcRelAssociatesMaterial'.

The orientation of a wall can be calculated from its local placement. Every entity that is a subtype of 'IfcProduct' has a placement. This can be either relative to the world coordinate systems (WCS) or the placement of another subtype known as an 'IfcProduct'. This is illustrated in Figure 1 which shows a plan view of walls with different orientations, and their possible coordinate systems. The walls face each other with respect to their internal sides. The origin of their coordinate systems will be at one of the ends of a wall. The 'DirectionSense' of an 'IfcMaterialLayerSet' entity can hold the value 'positive' or 'negative'. It can be used to determine whether the y-axis is pointing to the outside or inside of a wall. A unit vector is defined which points from the walls origin to its inner face. It is then translated to the WCS using transformation matrices. As the positive y-axis of the WCS by default points north, the orientation can now be worked out.

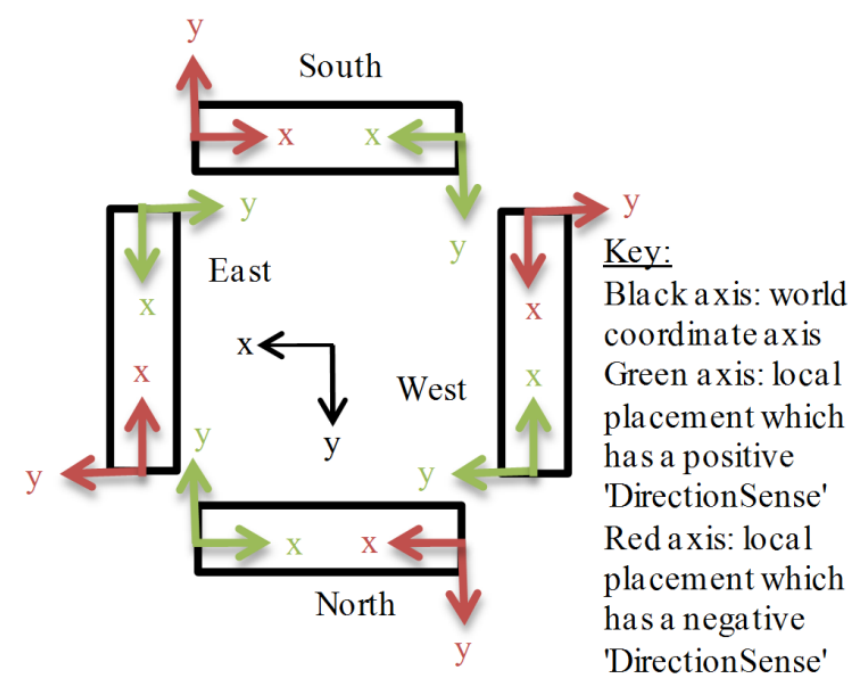

Figure 1 A plan view of possible local placements of walls with different orientations.

In order to extract geometrical data, the shape representation of a wall has to be analysed. The two wall types currently processed by PassivBIM are a 'SweptSolid' and a 'Clipping'. A 'SweptSolid' shape can be given by the 'IfcExtrudedAreaSolid' entity. This has the attribute 'Depth' (the height of a wall) and 'SweptArea'. The 'SweptArea' instance can be the entity 'IfcRectangleProfileDepth'. This has the attributes 'XDim' and 'YDim', which represent the wall length and width respectively.

A 'Clipping' is a shape that can be said to be initially represented by a 'SweptSolid', but it is then cut by planes. This is to take into account for example the joining of a wall to a roof. In this approach the process of clipping starts with the identification of the vertices of the exterior face of the wall. This needs to take into account that the sides (or cross sectional depth) of adjoining 
walls may form part of its front face. Wall connections are described by the relationship 'IfcRelConnectsPathElements'. The polygon formed by the vertices is then adjusted by an extended version of the Sutherland-Hodgman polygon clipping algorithm [50]. The depth of the lowest floor must then be added to the height of the wall face. Finally, the location of the thermal boundary is taken into consideration. If the thermal envelope ends at the level of the highest floor/ceiling (i.e. cold roof construction), then the wall face has to be cut such that any wall area above the insulated floor/ceiling height is ignored. If the thermal boundary is in the roof (i.e. warm roof construction), then the cross sectional thickness of the roof build-up must be added to the height of the wall face.

\subsection{Processing floor geometry}

Floors can be drawn in BIM tools to finish at either the inner or the outer face of an external wall. For a PHPP floor area calculation, the external floor dimensions must finish at the outer face, so using the floor slab as defined in an IFC file could lead to a floor area being wrongly evaluated. The solution to this issue is to use the IFC data on external wall connections. The whole floor area can be calculated based on the polygon drawn using the outermost corners of two external walls meeting. In Figure 2, vertex $\mathrm{V}$ is an example of the location of a corner such as this. The details on the connections between walls can be found in the relationship 'IfcRelConnectsPathElements'. Walls are described by this as either a 'RelatedElement' or 'RelatingElement', and can join as is depicted by Figure 2. They are also given a connection type, represented by the values 'AtStart' or 'AtEnd' which relates to the position of the origin of each wall placement in relation to the connection. The origin describes the origin of the walls local coordinate system. From this data, the coordinates of a vertex can be established. Using Figure 2 as an example, the first step in acquiring the location of "V" is by adding half the width of the 'RelatingElement' to its origin. This process has effectively moved the original origin point to the outer face of the 'RelatingElement'. As the 'RelatingElement' coordinate axis is in this case defined as 'AtStart', no further steps are required in order to arrive at the outermost corner of the connection between two walls, vertex V. If the 'RelatingElement' wall axis was described as 'AtEnd', the length of the wall has to be added onto the adjusted origin in order to travel along the wall's length and reach vertex $\mathrm{V}$. At this point, it is important to note that the origin is in the wall's local axis, so the coordinate of "V" has to be adjusted to make sure it is in the world coordinate axis. PassivBIM then searches for a connection related to one of the walls that has just been examined. The process used to determine the outermost corner in a connection is repeated, and eventually a closed polygon shape has been described. Once it is verified whether the shape has been drawn in a clockwise or anticlockwise direction, its area can be added to the total floor area value. This method can be used to calculate all the individual floor areas in a building.

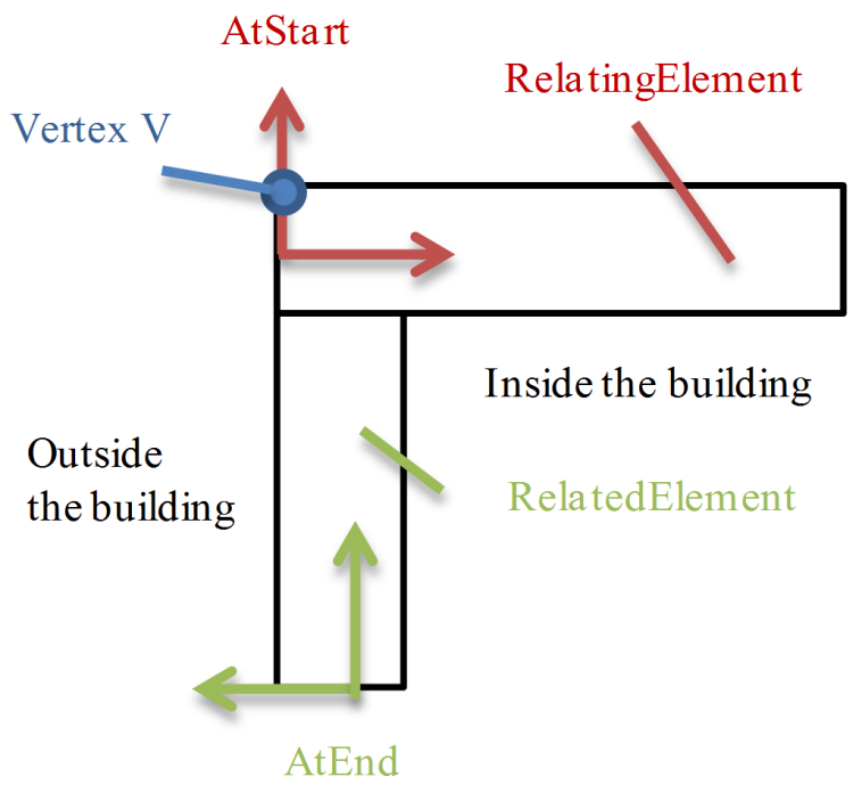

Figure 2 L-shaped connection between walls

\subsection{Processing window geometry}

The processing of window geometry is twofold. The window must first be classified with an orientation, and then its area is calculated. A window is related to an opening by the relationship 'IfcRelFillsElement'. An 'IfcOpeningElement' creates a void in a wall with the relationship 'IfcRelVoidsElement'. The steps that must be taken to find the orientation of a wall are given in section 4.1. The two relationships described above can be used to determine which wall a window is embedded in, and consequently what orientation it faces. The area of a window is the product of two of the 'IfcWindow' attributes: 'OverallHeight' and 'OverallWidth'. 


\subsection{Processing door geometry}

Doors can be either external or internal, which is documented in the property set 'Pset_DoorCommon', similarly to the wall described in section 4.1. The area of the external doors is calculated from the following attributes of each 'IfcDoor' entity: 'OverallHeight' and 'OverallWidth'.

\subsection{Processing roof geometry}

IFC roof geometry is composed of several individual slabs, linked together with the relationship 'IfcRelAggregates'. Similarly to the wall shape representation, it can be commonly a 'SweptSolid' or a 'Clipping'. The prototype currently supports the 'SweptSolid' type. The area corresponding to a roof in PHPP depends on the location of the thermal boundary. If the thermal envelope ends at the highest floor/ceiling (cold roof construction) then the external area of the highest floor/ceiling is the roof area required by PHPP. If the thermal envelope is located at the pitched roof plate level (warm roof construction) then the roof cassette area is required (Figure 3). In this project, two main assumptions were made in order to locate the thermal boundary: (a) the entity 'IfcSpace' is a thermal area and (b) if a space shares a boundary through the relationship 'IfcRelSpaceBoundary' with a roof cassette, the thermal boundary is in the roof.

If the external roof cassette area is needed, any overhangs need to be removed as is shown in Figure 3 . The highest floor is projected onto the plane of the 'IfcExtrudedAreaSolid' which is related to the roof cassette. This is done by finding the intersection of the horizontal vectors located at the floor vertices with the $\mathrm{z}=0$ plane of the 'IfcExtrudedAreaSolid' coordinate system. The floor edges are then used as a template to cut off the roof overhang using a second adaptation of the SutherlandHodgman polygon clipping algorithm [50].

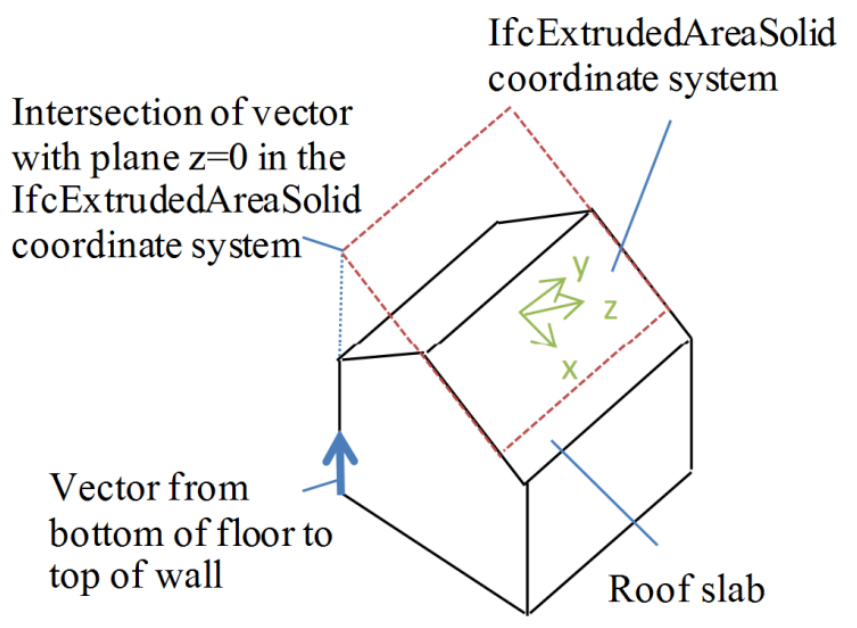

Figure 3 The removal of the overhang in a roof slab.

\subsection{Processing TFA}

The TFA relies on the 'If $c$ Window' for reveal areas, and 'IfcSpace' for floor areas. In order to qualify for the TFA, rooms must have a height of over $2 \mathrm{~m}$. This is checked automatically by PassivBIM. If a room has a height of $1-2 \mathrm{~m}$ half of its floor area can be included in the TFA, this is also checked by PassivBIM. Some areas are not allowed at all, for example where there are three or more stairs. These areas must not be defined by the user in the BIM tool to result in an 'IfcSpace' being exported. Only a certain percentage of certain other areas are allowed due to the nature of a space [48]. The eligible ratio of a space being put forward for the TFA can be manually altered through the 'Description' attribute of an 'IfcSpace'. Currently, if the value of this attribute is a decimal figure, the product of that figure and the space area counts towards the TFA. Additionally, eligible window reveal floor areas must have a reveal depth greater than $0.13 \mathrm{~m}$, and they must also be full height windows (i.e. starting at floor level) .

PassivBIM can process 'IfcSpace' entities which have the representation type 'SweptSolid' or 'Brep'. For a 'SweptSolid', the attributes 'Depth', 'XDim' and 'YDim' (described in section 4.1) can be called upon to calculate an area and check the height of a space. A 'Brep' representation is composed of many faces. These are defined using three or more coordinates. Each face in a 'Brep' is checked to see if it forms part of the floor of a space, and if the height of the space is above $2 \mathrm{~m}$. The floor area calculation needs to be extended in the future so parts of a representation can be are eligible for the TFA. Any windows next to spaces are currently identified using the 'IfcRelSpaceBoundary' relationship, so their reveals can be analysed. The 'IfcWindow' shape is composed of a plethora of extruded polygons. In order to calculate a reveal, the smallest distance between the inside of a window and the first extruded shape surface needs to be established. This is done by comparing coordinates that are at the beginning and at the end of extruded polygons. 
The next section will give more details on the methodology behind the development of PassivBIM.

\section{METHODOLOGY}

As this project is supporting the tool PHPP, the system needs to be compatible with MsExcel and be able to read IFC files. One of the aims of this project is to produce a non-proprietary solution to geometry extraction, which is compatible with a range of BIM authoring tools. By using the IFC schema, the system remains generic and it can be applied to any BIM authoring tool that exports IFC files. Another aim is to address the need to store behavioural data alongside static data such as geometry [52]. One of the limitations of storing increased amounts of data and potentially algorithms inside the IFC global schema itself is the obvious expansion of file sizes and additional computational burden. In addition energy calculation methodologies vary from tool to tool and there are clearly finite limits on the number of methodologies which could be supported within a single schema. The extension of the IFC schema is therefore achieved largely via external coupling. Although there is potential for the future inclusion of the thermal properties of the materials within the IFC schema itself, external coupling allows for the inclusion of the terms required for the heat demand calculations, as well as opening up the possibility for post processing and exporting the analysis results.

An overview of the proposed PassivBIM system is shown in Figure 4. This demonstrates that input into the system can come from a BIM tool (data flow in green), PHPP (data flow in blue) and from a user (data flow in yellow). Currently the BIM tool provides geometrical data, and PHPP and user input is used as a source of non-geometrical data. The input from the BIM tool is in the form of an IFC file, which can be read directly by the PassivBIM Java tool. An XML template tool is used to extract non-geometrical data from MsExcel (i.e.the PHPP file) to an XML file, which can be read directly by the PassivBIM Java tool. Once geometrical data is processed and the performance of the building design has been evaluated and optimized the data is inserted back into PHPP directly using the PassivBIM Java tool. Alternatively, it may also be exported as an XML file.

The ability to export into an XML file is automatically available due to the process of generating Java classes from XSD schemas. These exported files are illustrated in the data flow diagram as they are considered to have the potential to support collaboration. They can be uploaded onto an online XML database, and accessed by, for example, various project partners. This is a useful feature for multi-disciplinary project collaboration, as the size and content of the XML file can be chosen by the user since they have a choice of which entities (and inherently which sub entities) are exported. This is very different to an IFC file, which contains all the information about a building in one file. It is important to note however that the significant end product of the PassivBIM tool is not to export XML files, but to export data about an optimised building solution back into PHPP. At present it is significant that this information can be entered easily back into PHPP, as this is the only officially approved design tool that can be used to verify a certified Passivhaus design.

Using a tool like PassivBIM has significant advantages beyond Passivhaus compliance or certification. It provides the Architect or Passivhaus designer an opportunity to visualise the building and ameliorate its performance with design aides such as an optimisation algorithm for building elemental areas. The option of re-exporting optimised geometric data back into an IFC file was considered, but not followed through. A number of attempts at 'roundtripping' in Revit and in another IFC visualisation tool called IFC “demo viewer" (exporting a file and trying to import it back into Revit) showed the software was not ready to be used as a validation tool of the consistency and accurateness demanded by IFC files. Errors encountered involved: building elements loosing geometrical data, custom made windows loosing transparency and walls not ending at the roof.

The methodology to create the PassivBIM Java tool consists of the following steps:

1) Extending the IFC schema with an energy domain. The energy balance equations used in this extension all originate from PHPP, and the structure of the extension is based on the existing IFC structural analysis domain. More details on the extension can be found in section 5.1 .

2) Using the extension used to extract data from PHPP. This is based on a template document set up in MsExcel which takes data from a PHPP document (via Visual Basic macros) and exports it as an XML file which can then be read by PassivBIM. More details can be found in section 5.2.

3) Generating a tool based on the extended schema in the Java programming language. This tool imports all the data necessary to perform a simplified PHPP heating demand calculation, performs the calculation and then offers the user some optimisation capabilities. More details can be found in section 5.3, which include details of how it reads IFC and XML files, and inserts data into PHPP. 


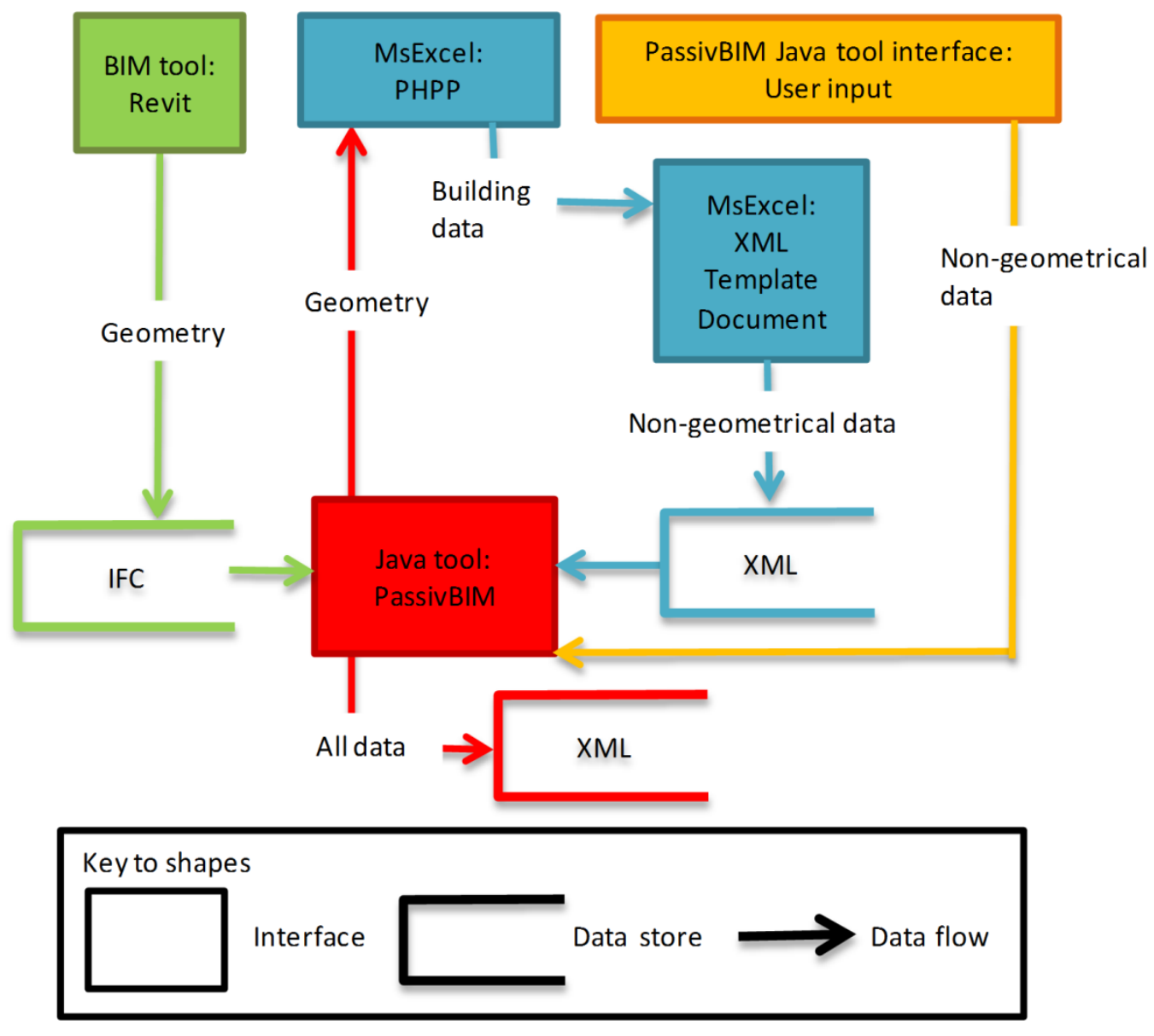

Figure 4 A Gane-Sarson diagram showing a high-level view of the data flow of the PassivBIM system.

\subsection{IFC Energy Extension}

There are many versions of the IFC schema, and the one extended in this project is the IFC 2x3 TC1. The IFC schema is available in both the EXPRESS and XML language. The XML version, IfcXML, is an XSD schema that is extensible without the need to edit the original schema. As the IFC schema is complex, and not all of it is necessary to describe certain exchanges of information, subsets of the schema can be exchanged using a 'Model View Definition' (MVD) [49]. One example of a MVD documented by BLIS Consortium [49] describes the data exchanged from 'Architectural Design to Building Energy Analysis'. An input file which adheres to this MVD could be used as an input file to PassivBIM. The project cannot claim however to be compliant overall with any existing MVD, as its objective is to extend the current schema and thus it will be inherently incompatible with any existing MVD.

The IFC schema contains a range of domains, but although an energy analysis MVD has been developed [49], the schema currently lacks a domain that could be used to describe an EN13790 compliant energy analysis. The first stage in developing such a domain involved identifying specific key energy concepts used by PHPP in the annual heat demand calculation (Table 1). The IFC schema was then analysed to see which existing parts could be effectively incorporated. These include:

- ' IfcBuilding'. This stores the buildings name, type and address.

- A range of 'defined types' from the 'IfcMeasureResource' such as 'IfcAreaMeasure', 'IfcSpecificHeatCapacityMeasure' etc which can be used by concepts to hold data.

- ' IfcZone'. Only one instance is necessary for a PHPP calculation as this tool assumes there is only one thermal zone.

- The structural analysis domain. The structure of this domain and the terminology is imitated in the proposed energy analysis domain. The main supertypes of the structural entities are also used as an entry point for energy concepts into the IFC hierarchy, such as 'IfcSystem', 'IfcGroup' and 'IfcProduct'.

- Property sets. Two specific property sets were identified as particularly useful: 'Pset_DoorCommon', 'Pset_WallCommon'. They include a property 'IsExternal' which can be used to identify if walls and doors are external, and therefore if they should be included in the thermal envelope area calculation.

- The entity 'IfcSystem' is used to represent the ventilation system. The entity 'IfcEnergyConversionDevice' is used to represent both the sub soil heat exchanger (where present) and the heat recovery unit. The instances of these entities are linked to user-defined property sets using the relationship 'IfcRelDefinesByProperties'. The user-defined property sets contain a single property: efficiency. The two instances of 'If EEnergyConversionDevice' can be linked to object type 
entities using the relationship 'IfcRelDefinesByType'. Type objects enable the definition of more specific details about objects. The two specific types that are relevant are the 'IfcAirToAirHeatRecoveryType' for the heat recovery unit, and the 'IfcHeatExchangerType' for the sub soil heat exchanger. The common property sets describing these object types do not currently describe the efficiency. These property sets are therefore not used by the PassivBIM system. It should be noted that in the newest version IFC4, (released officially in March 2013) there are some changes to the schema in this area. The entities 'IfcAirToAirHeatRecovery' and 'IfcHeatExchanger' are added to the schema. In addition, the property set 'Pset_AirToAirHeatRecoveryPHistory' can be applied to the entity 'IfcAirToAirHeatRecovery' to describe the efficiency with properties such as 'TotalEffectiveness'.

- The 'IfcShapeRepresentation' entity and its attributes describe geometry of building elements.

Figure 5 is an EXPRESS-G diagram of the key concepts used to extend the main IFC schema. The diagram illustrates the existing IFC elements from which the extended schema originates. The existing entities are 'IfcSystem', 'IfcGroup' and 'IfcProduct'. Entities are represented as yellow boxes in an Express-G diagram, and the roots of a hierarchical structure are grey and their names are preceded with the name of the IFC data model they originate from. The boxes represent entities in the IFC schema, and their attributes have not been included. A more detailed version can be found in the Open IFC Tools resource [53], which represents the formal definition of the proposed extension. The extension concepts provide a mechanism to describe thermal items, activities and groups. The items include physical items, such as building elements. Examples of thermal activities include transmission and ventilation. The groups (signified by the ABS prefix) link activities to represent total heat loss, heat gain and the 'IfcEnergyAnalysisModel'. This last entity connects the type of analysis, building elements and thermal load groups. The derivation and insertion of these new entities into the IFC schema has been largely influenced by the need to add entities to hold important data parameters that need to be entered into PHPP, and also to describe the results of its energy balance calculations. For consistency with the existing IFC structure the form of these concepts largely reflects the pattern established by the existing 'IfcStructuralAnalysis' domain.
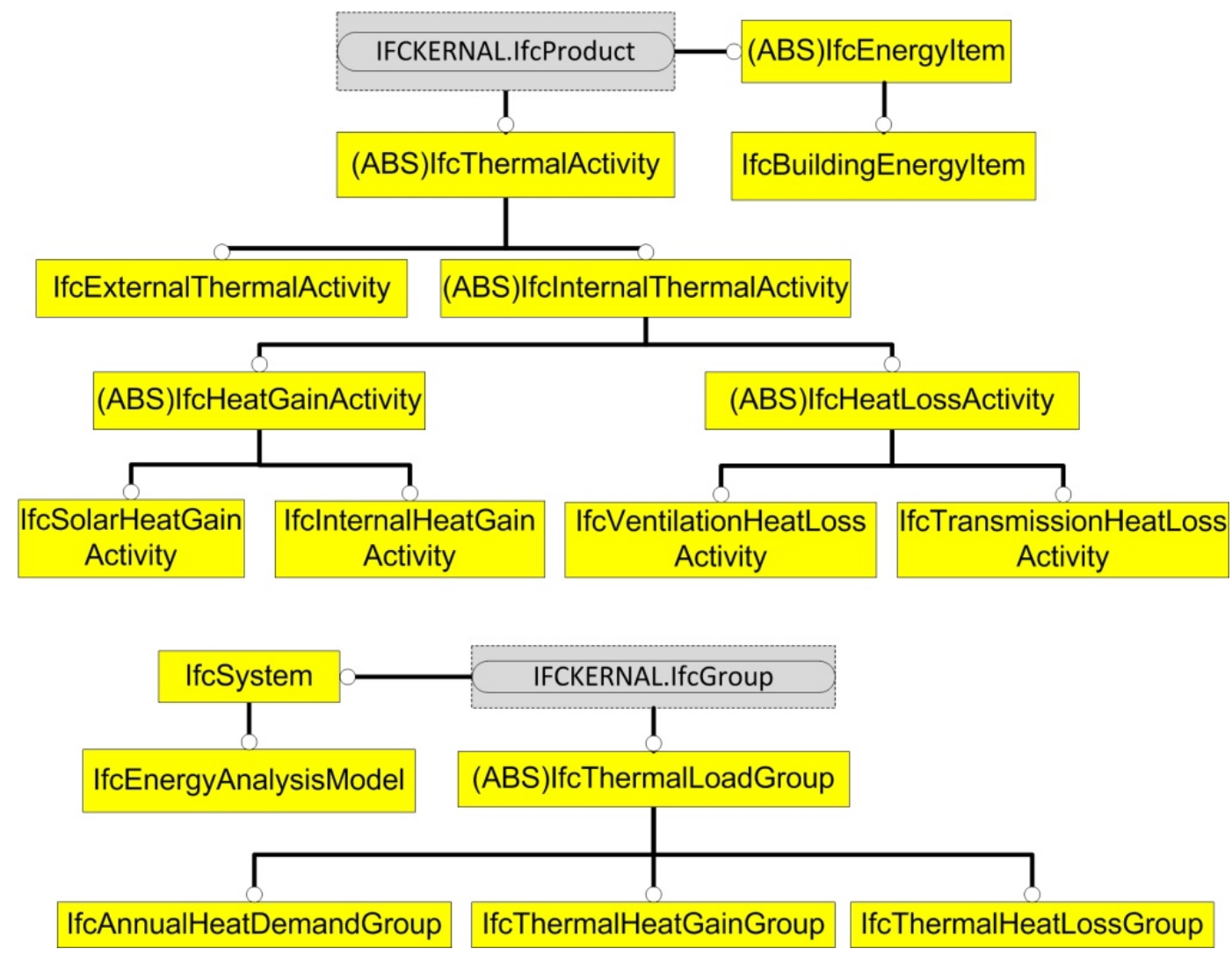

Figure 5 Express-G diagram of existing and proposed entities in the main part of the IFC schema

The extended schema also has an energy resource, shown in Figure 6. Entities described in a resource data model sit outside of the main IFC data model. This includes sub models such as 'IfcCostResource', and 'IfcMaterialPropertyResource', which can be found on the IFC architectural diagram [25]. They are linked directly to IFC 'DefinedTypes', which can store alphanumeric data. Entities stored in a 'resource' data model, rather than in the main IFC model, can be used to describe attributes of entities from several domains. The 'IfcEnergyResource' contains concepts that are used to describe the attributes of entities in the energy extension of the main IFC schema (shown in Figure 5). For example, the 'IfcBuildingEnergyItem' has an attribute called 'AverageUValue', which is linked to the entity in the energy resource 'IfcUValue'. This is in turn linked to an existing DefinedType called IfcThermalTransmittanceMeasure', which can hold numerical data. Use of this type of structure for data storage is very common in the IFC data model. 


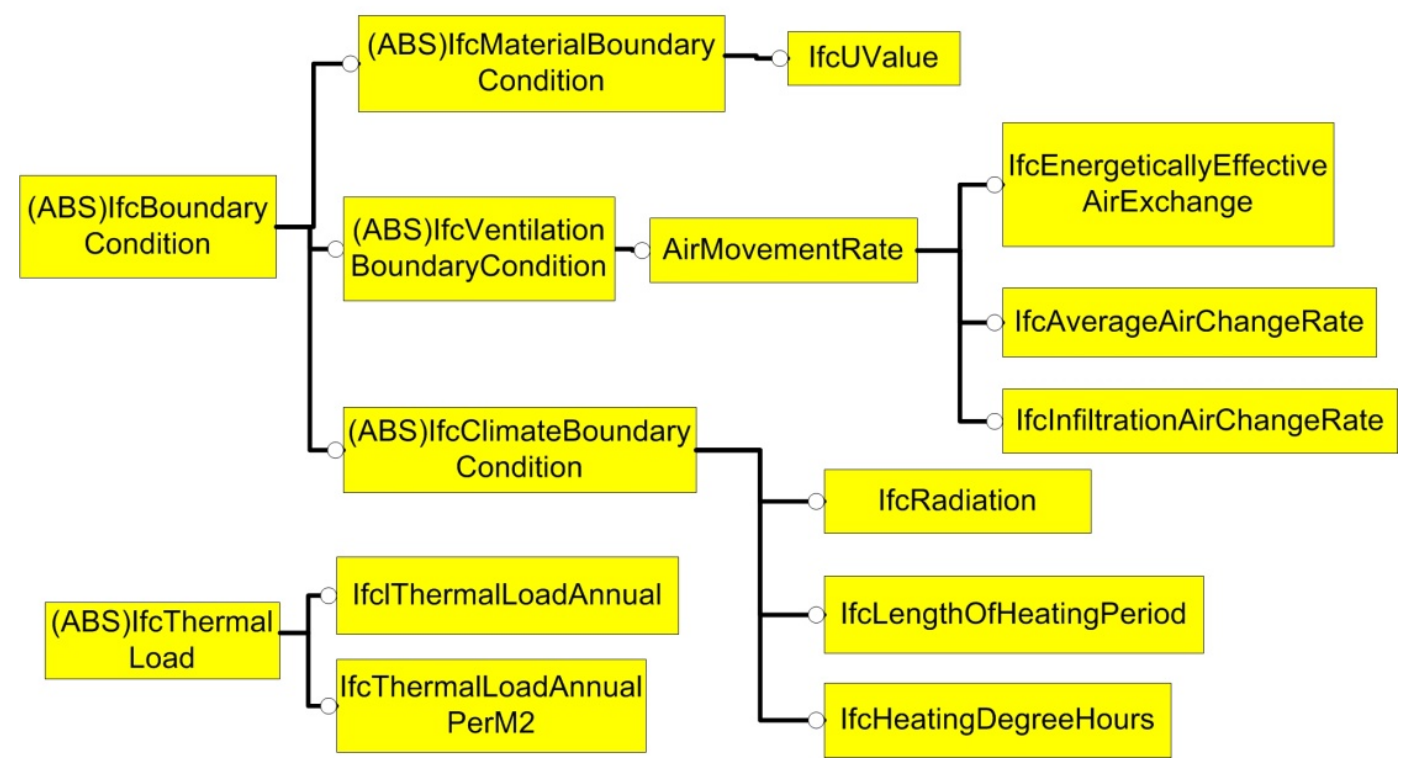

Figure 6 Express-G diagram of the proposed entities for an IFC energy resource

A completely new entity and relationship has been added to the IFC schema as part of the extension, which has no counterpart in the structural analysis domain. The 'IfcDesignAlternative' entity contains information on alternative building elements and climates files, using the entities 'IfcAlternativeClimate' and 'IfcAlternativeBuildingElement'. The purpose of this entity is to hold details of alternative building strategies. This function is particularly useful in design and cost optimization analysis, where for example an architect may be testing different building forms (area to volume ratios) or comparing the performance implications of various products. The new relationship 'IfcRelConnectsDesignAlternative' is a mechanism that enables alternative designs and their energy consumption to be linked to a base building model. This enables alternative building designs to be stored side by side and comparisons to be more easily undertaken by the design team.

\subsection{MsExcel XML Template Document}

As the energy extension is in the format of a XSD schema, it can facilitate the export of data from PHPP models into an XML document. MsExcel has a functionality where XSD schemas can be imported into an active workbook, and then cells in the workbook can be mapped to the concepts described in the XSD schema. Once mapped, the contents of the cells can be exported to an XML file. This function was used to create a MsExcel file called 'XML Template', which has cells in one of its spreadsheets mapped to an XSD file containing a simplified version of the extended IFC schema. To be compatible with MsExcel, the extension had to be simplified and unlinked from the IFC 2x3 TC1 schema. This process was necessary, as some XML tags used to describe the IFC schema are not compatible with the exportation process of MsExcel. The simplified extension was then reused to generate Java classes using software called Liquid XML Studio 2011. These classes contain algorithms that can read the exported XML documents from the XML Template. Once transferred the data stored in the Java classes is accessible to the main PassivBIM Java tool.

A macro was then designed and added to the XML Template document, which allows data to be extracted from an existing PHPP file and loaded into the XML Template document. This data contains important information about the thermal transfer properties of individual construction elements (which is currently not available in the IFC schema). Once extracted this data can be exported into a XML file, which can be read by PassivBIM and used to calculate the buildings heat demand. This process relies inherently upon data such as U -values and thermal bridge lengths having been entered into a PHPP document by a competent user (such as an architect or Passivhaus designer). The user then simply enters the file name of the relevant PHPP document into the XML Template Document, and uses MsExcel to export an XML file. The PassivBIM tool can then use the data in its calculations. In terms of the actual calculations performed, at present the tool only performs the six core heating demand balance equations which are described in the PHPP 2013 handbook, (version 8, pp113-121) [47]. These equations generally comply with the procedures set out in EN13790 [47]. If all the data from a PHPP file was used by PassivBIM, the calculated heat demand would be precisely the same as that calculated by PHPP. The aim of using this template therefore is simply to extract the non-geometrical data which is currently unavailable in an IFC file created by a BIM tool. This process is explained in more detail in the next section.

\subsection{PassivBIM Java tool}

The aim of this part of the PassivBIM system is twofold. Primarily, it is an example of an implementation of the extended schema, showing how building information and simulation results can be stored together. The secondary reason is to provide a prototype that would automate some of the steps necessary to define geometry for a PHPP model from an existing BIM model. In order to fulfil the first purpose and create a tool which utilises the IFC extension: 
- $\quad$ An XSD file was created which contains the energy analysis IFC extension.

This was linked to a file describing the full IFC schema, by describing its location in the XSD file header. This enables mechanisms to be used in the definition of an extension, such as the derivation of new concepts from pre-existing entities in the IFC schema, and the use of existing DefinedTypes to store attribute data of new entities.

- Liquid XML Studio was then used to convert this XSD file into Java classes. These classes form the basis of the PassivBIM tool, and allow XML files to be read and output by a Java tool in a format which is compliant with the energy extension.

- The steps above had to be repeated using a simplified version of the IFC extension, which was unlinked from the full IFC schema. This is due to MsExcel, the tool used to generate XML files for PassivBIM, not being compatible with many of the mechanisms used in the full IFC XSD file. In summary, the PassivBIM tool uses the simplified extension Java classes for reading XML files, but then stores the data using the full extension Java classes. This means any XML documents generated using the Java tool, for example after an energy analysis calculation, are compliant with the full extension. This step could be bypassed by further developing the tool to directly extract data from MsExcel.

- Java packages from the Open IFC Tools project [54] are used to read IFC files, and store data. The packages enable the storage of data in classes with the same names as the concepts in the IFC schema. Java algorithms were then written (based on section 4) which processed the retrieved geometrical data in order to be able to use it for PHPP annual heat demand calculations. This includes for example iterating through a list of instantiated classes until its name is equal to 'IfcWall', then accessing all of its attributes through various class based functions, to identify for example whether it is an external or internal element. A more in depth discussion on the manipulation of geometry, including the transformations necessary can be found in [53].

- $\quad$ Packages from the project Apache POI [55] were added to the PassivBIM tool to enable reading and writing directly to an MsExcel file. This enables data to be transferred back into PHPP. Apache POI is an application programming interface (API) for Java tools which enables them to access Microsoft documents. It is composed of many libraries of Java classes, one of which is the 'HSSF' library which is targeted at MsExcel '97. This library is utilised by PassivBIM as the PHPP spreadsheets are commonly saved in this version. The Apache POI website [55] provides guidelines on how to use the library so this information will not be repeated here. A general overview of the process can be summarised as follows: the target PHPP file is read as an input stream, individual worksheets are referred to in the spreadsheet, and cells are identified that will have data transferred to them. Cells contents are then updated with the pre-prepared values and any cells which are reliant upon other cells (such as total areas) are refreshed using an 'evaluator' function.

The Java tool was then further developed to enable pre- and post-processing of the data, including calculation of the heating demand and performing optimisation tasks that can inform decision-making. These tasks are currently simple examples which highlight the further potential of PassivBIM.

Figure 7 is a UML case diagram of how architects and Passivhaus designers would interact with the PassivBIM system. The first step is for an architect to create a Revit model of a building, and export an IFC file. Additional input is then entered by hand, or via an XML document generated using the Template document if selected. The latter reduces data entry repetition and the risk of human input errors. The calculation of areas relies on many rules in order to decide where the thermal boundaries are in a building. Examples of decisions include determining the orientation of building elements, deciding if specific wall areas need to include the cross sectional areas of adjacent walls as they abut but do not overlay in an IFC file and if the thermal boundary is located at the ceiling or roof level. Post-processing of the data then removes unwanted areas such as an overhang and adds in areas such as the cross sectional thickness of a ground floor, where required, to meet the PHPP balance boundary criteria. It must be noted at this point that the the role of an architect and Passive House designer have been consciously separated in Figure 7 to introduce clarity. In reality, the roles are not as clear as the PassivBIM tool could be equally useful to the Passive House designer, and many architects may be themselves the Passive house designer. 


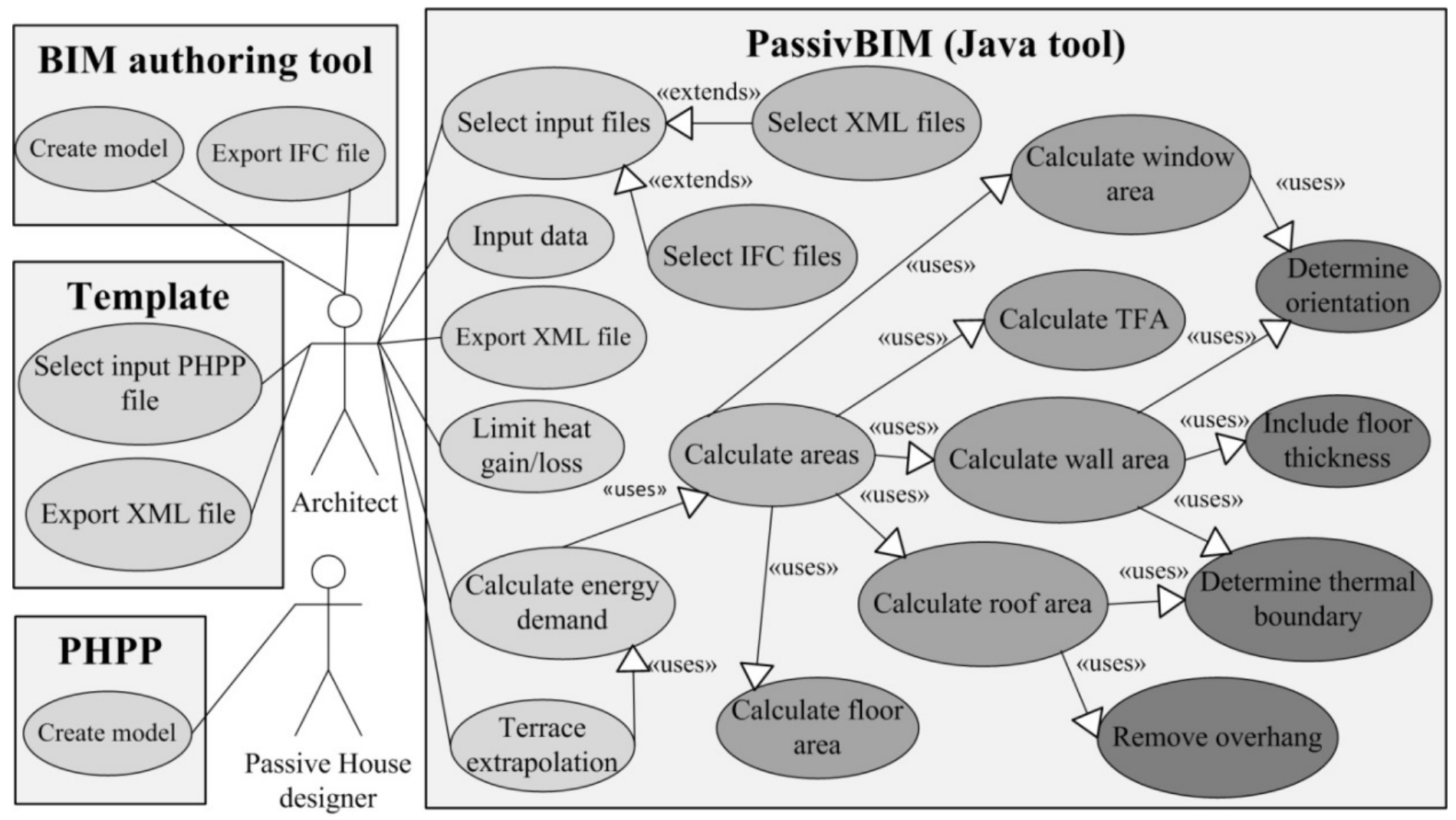

Figure 7 UML case diagram of the interaction between Architects, Passivhaus Designers and PassivBIM

The next section describes in more detail the case studies used to test the main Java tool. Using proprietary BIM generated IFC files presented an opportunity to determine commonly exported geometrical representations of IFC entities such as an 'IfcWall'. This is an important interim validation process, as the tool is a proof of concept and does not currently need to handle all possible IFC representations. Two main studies, detailed below, were used to validate the process of extracting geometry.

\section{HANNOVER KRONSBERG, GERMANY}

The first study is based on buildings from a social housing estate in Hannover Kronsberg, Germany. They are certified as Passivhaus compliant, and their performance has been validated by measured results [17]. The aim of this study is to show that PassivBIM can process: (a) buildings in terraces that have party walls, (b) two buildings in a single IFC file, and (c) a middle and end terrace house to inform design decisions during project masterplanning. The buildings all have their uppermost thermal boundary located in the roof (i.e. warm roof construction). This case study informed the development of algorithms that can deduce the location of the thermal boundary, and process representations of walls and roof constructions to provide the correct roof and wall, balance boundary, areas. These algorithms also remove overhangs from the roof area (as described in section 4.5). Figure 8 shows the south facades of part of the terraced row. The buildings at the end and in the middle of the terrace are called 'Endhaus' and 'Mittelhaus' respectively, but in this paper they will be referred to by their English translations as the 'end house' and 'middle house'.

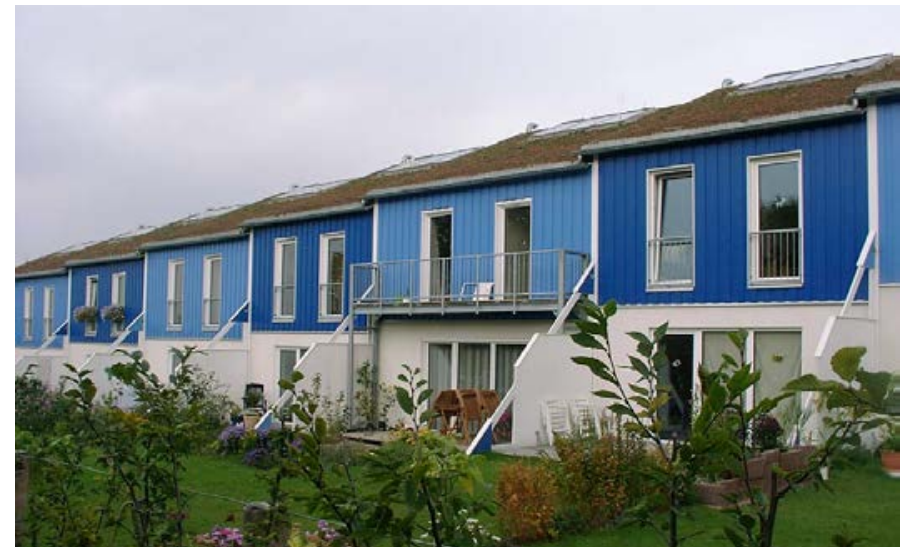

Figure 8 South facades of the Kronsberg, Hannover Terraces [56] 
Middle house and end house data can be found in a report by Feist et al. [56]. They both have the floor plan referred to as 'Jangster de Lux', but they have different types of external walls. Non-geometric (materials) data from the report was manually entered into PassivBIM. Most of the necessary building dimensions are available in the floor plans, but some internal dimensions had to be extrapolated from the drawings. A summary of the areas used is presented in Table 2. From this table it can be seen that the middle house and end house do not have an area designated for the external door. In the original report [56], the external doors were not assigned an area, so in order to enable a comparison of results in this publication this was reproduced. The south facing doors can be seen in Figure 8 on the ground floor, but it is assumed they were included in the thermal specification as windows due to their construction being mostly glass. The main entrance doors are located on the north side of the dwellings and are not shown here.

Table 2 Area properties in $\left(\mathrm{m}^{2}\right)$ of the case studies, data taken from [56].

\begin{tabular}{|l|l|l|l|}
\hline Building elements & $\begin{array}{l}\text { Middle } \\
\text { house } \\
\left(\mathrm{m}^{2}\right)\end{array}$ & $\begin{array}{l}\text { End } \\
\text { house } \\
\left(\mathrm{m}^{2}\right)\end{array}$ & $\begin{array}{l}\text { Larch } \\
\text { House } \\
\left(\mathrm{m}^{2}\right)\end{array}$ \\
\hline External door & 0 & 0 & 2.37 \\
\hline Floor slab & 71.76 & 76.99 & 63.88 \\
\hline North windows & 8.60 & 8.60 & 4.07 \\
\hline East windows & 0 & 0 & 4.39 \\
\hline South windows & 11.40 & 11.40 & 28.07 \\
\hline West windows & 0 & 0 & 0 \\
\hline $\begin{array}{l}\text { Exterior Wall (Without } \\
\text { windows/doors) }\end{array}$ & 56.32 & 149.57 & 176.66 \\
\hline Treated Floor Area & 120.61 & 120.61 & 86.69 \\
\hline Roof & 78.25 & 83.96 & 63.88 \\
\hline
\end{tabular}

The first part of the study involved IFC files representing the middle and end house terrace. All external walls must be labelled 'external' in Revit in order to be processed correctly by PassivBIM. The second part of the study used an IFC file consisting of two end houses side by side, separated by their party wall (so as to form a semi-detached dwelling sharing a common thermal envelope). The end house model was created for both the left and right end of the terrace in Revit, and the two models were 'linked' and 'exploded' into a single file. Non-geometrical data is the same as for the end house, with the exception of the thermal bridge areas. Thermal bridging data is typically calculated using a finite element model, but as the buildings are identical in this case and the linear thermal bridge values known, the thermal bridge lengths were simply doubled. In the third part of the case study, PassivBIM is used to generate performance graphs that show the average energy consumption of all the buildings in a range of terraced buildings. This process needs a model of an end house and a middle house. It then creates scenarios by composing them into terraces. Figure 9 shows terraces with theoretical compositions of two, three and four buildings. The middle house has two exterior walls and two thinner interior walls, and the end house has three exterior walls and one interior wall. From the building plans shown in a report by Feist et al. [56], these two types of floor plans were joined together to make terraces. This possibility shows a useful practical application of PassivBIM whereby the real world impact of changing surface area to volume (SA/V) ratios on final energy demand can be rapidly assessed. This type of analysis is one of the fundamental concepts involved in passive building design optimization [57], and in Figure 7 this is referred to as 'Terrace extrapolation'.

Houses

2
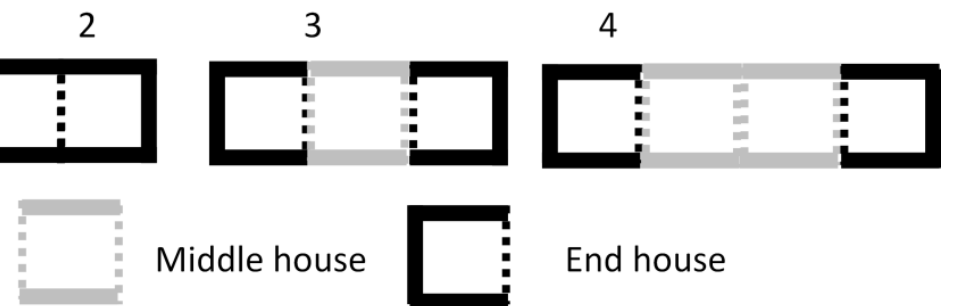

Middle house

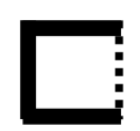

End house

Figure 9 The composition of houses in a terrace

\section{LARCH HOUSE, WALES}

The second study is a building in Ebbw Vale, Wales, called the Larch House. Figure 10 shows a picture of this detached certified Passivhaus. It was completed in July 2010, but monitored data has not yet been published. It was the first examples of a certified UK Passivhaus which also met Code Level 6 (zero carbon) of the Code for Sustainable Homes and is used as a future prototype of low energy social housing [58]. There are three main aims of using this case study. The geometrical extraction of the Java tool is further validated using a detached building model, which had the upper thermal boundary in the ceiling plane (i.e. cold roof construction). It informs the development of an algorithm that evaluates window geometry to establish whether reveals should be 
included in the TFA. Finally, validated models are evaluated using optimization routines to show how design decisions could be informed by optimising individual building element properties. In this example, the annual heat demand is limited (by setting a maximum exceedance threshold), and the consequential implications for building element areas is back calculated. Geometrical data for the building originates from architectural plans, and the areas of building elements are shown in Table 2.

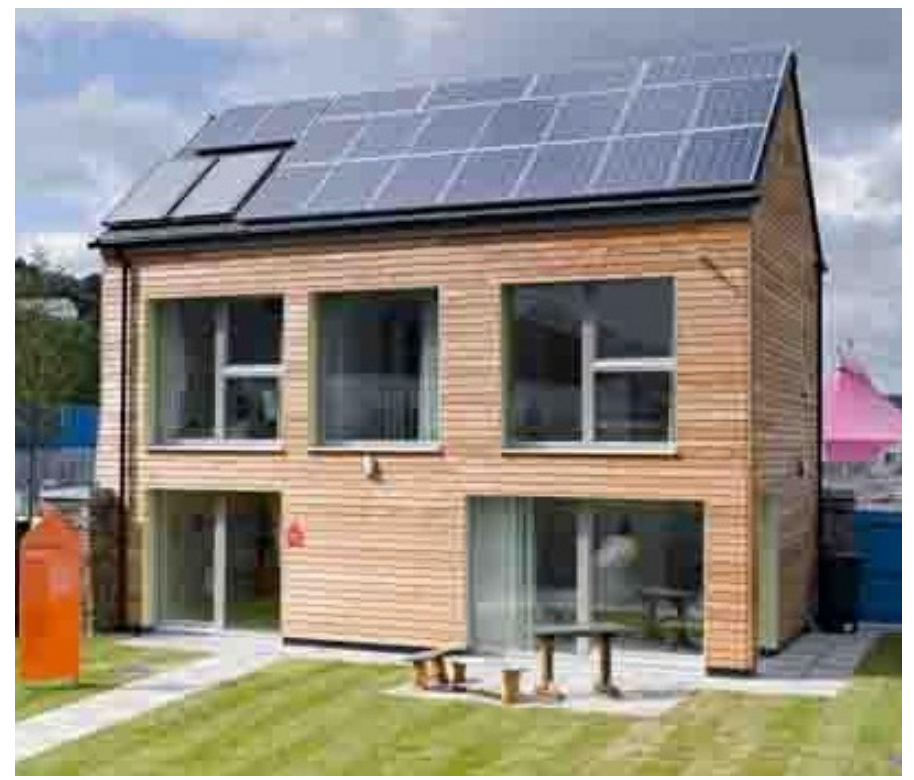

Figure 10 The Larch House case study [58]

Only one IFC file is necessary for this study, additional information about weather files and non-geometrical data comes from XML files generated by the Template document from PHPP. The initial model uses an Ebbw Vale climate file to validate the Larch House model against existing data. Two further models are set up for comparison, placing the same building under a 'London CBD' climate, and a future climate called 'London CBD2080M50\%'. These probabilistic climate files were generated and validated in a study by McLeod et al. [19]. The future climate is for a median estimate of change, based on downscaling of the IPCC Medium emissions scenario and in the year 2080. It is interesting to note that the latitudes of the weather files are very similar, with Ebbw Vale having a latitude of $51.76 \mathrm{~N}$ and London CBD having a latitude of $51.53 \mathrm{~N}$.

\section{RESULTS AND DISCUSSION}

The PassivBIM system has successfully extracted geometry from both terraced and detached buildings. The process highlights some issues with both the Passivhaus standard and IFC exportation. For the standard rules to be fully automated, some criteria need to be more rigorously defined. For example, the TFA calculation states that the reveal areas of full height windows can be included in the TFA. In reality, this window may be positioned a couple of centimetres below or above the finished height of a floor, so a tolerance level $(+/-\mathrm{x} \mathrm{cm})$ needs to be agreed. In terms of IFC exportation, the value for the true north was not accurately exported by the BIM tool used (Autodesk Revit Architecture 2012). The true north value should default to the positive direction of the $y$-axis, and the coordinate ' $(0,1,0)$ ' is expected to be exported. The coordinate actually exported was ' $(2,0,1)$ '. This was further tested with other rotations of the building, to find that the first value in the coordinate was always ' 2 ', and if the second two values were used to represent ' $x$ ' and ' $y$ ' values, they gave the correct direction.

Exported IFC files were also re-imported back into Revit to test IFC interoperability. Figure 11 shows a 3D view of (a) the Larch house Revit model and (b) the Larch house IFC file imported into Revit. Alongside some loss of information, the most noticeable problems are that windows have lost transparency and walls are not cut accurately. Another limitation arose when windows were inserted into a wall at the floor height on the first floor. The wall was subsequently exported using a representation that lost some parametric information, whereby the representation IfcWall was exported instead of 'IfcWallStandardCase'. When these windows were positioned at least $1 \mathrm{~mm}$ above the floor, the walls were exported with the correct parametric information. 

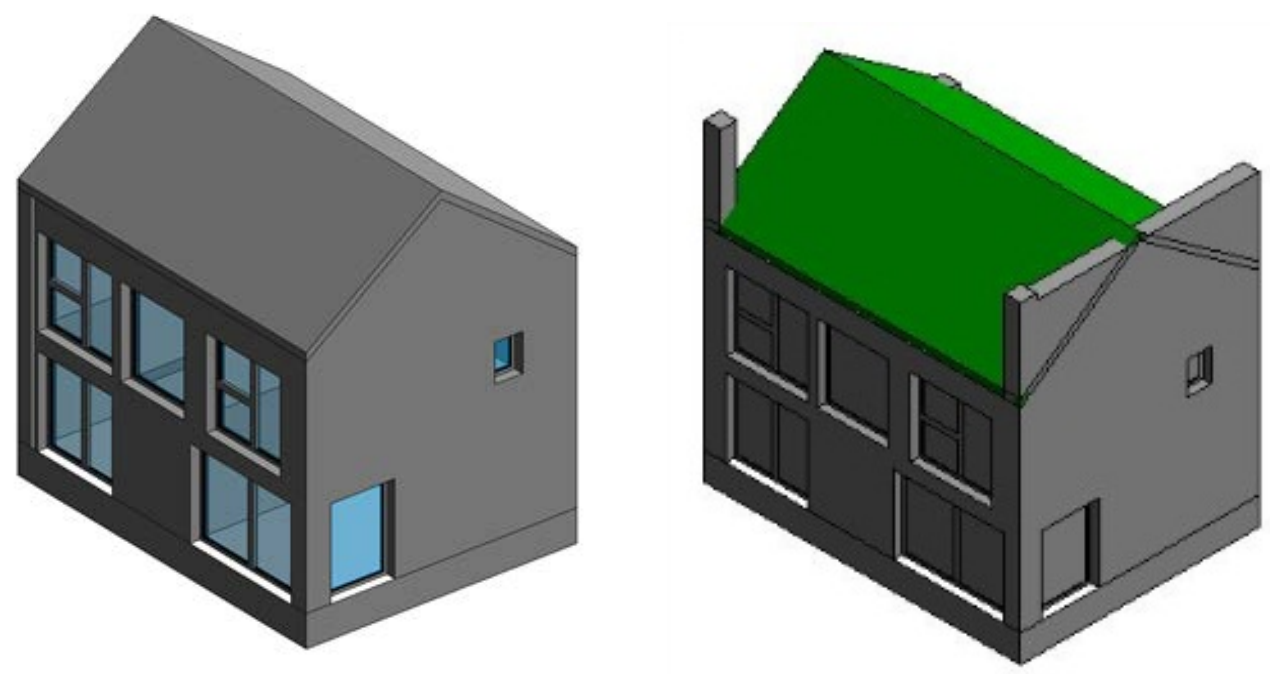

Figure 11 Larch house in Revit (a) view before export and (b) after export to IFC and re-importation to Revit

The sections below validate the Hannover Kronsberg and Larch House models against published data, and provide examples of PassivBIM informing design decisions.

\subsection{Validation Study 1 - Hannover Kronsberg, Germany}

There is a high level of agreement between the simulated and published Figures [56] of the total heat demand for the middle and end house. PassivBIM calculated heat losses and gains are shown in Figure 12, normalised to their respective TFAs. The percentage difference in heat demand between the middle and end house (referred to as Mittelhaus and Endhaus respectively, in the official project report) and that calculated by PassivBIM is only $2.85 \%$ and $1.59 \%$ respectively.

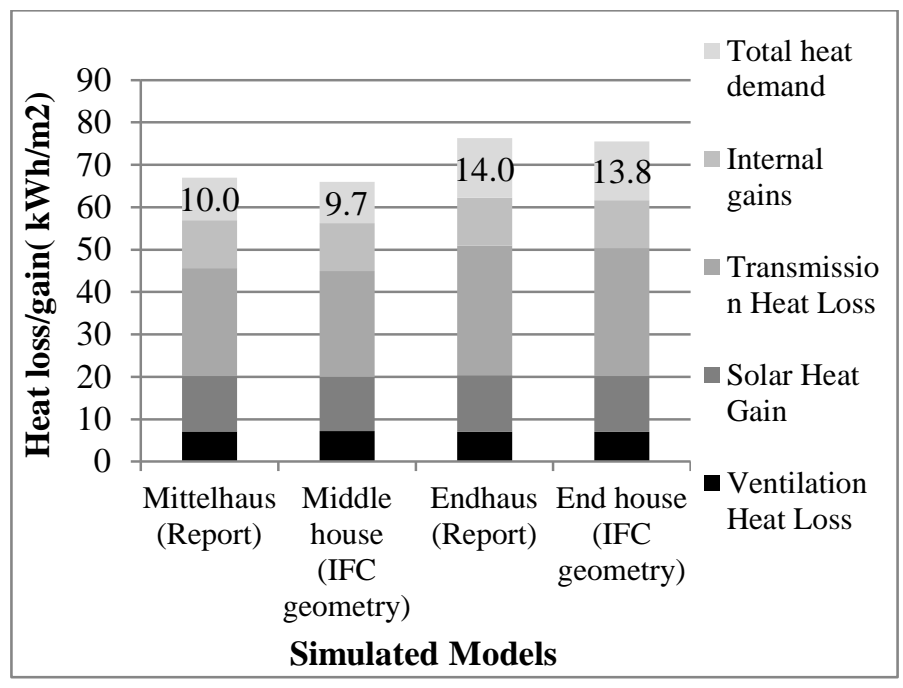

\section{Figure 12 Heat transfer in Hannover buildings}

As the middle house only has two external walls opposed to the three in an end house, it has a reduced heat loss area and consequently a smaller heat demand. In a SA/V study, PassivBIM can predict to what extent having more buildings in a terrace is an effective low energy design strategy. PassivBIM can also process data for a row of terraced buildings. Figure 13 shows the absolute (total) heat demand for an end house that has not been normalised by the TFA, and two end houses in one IFC file that have and have not been normalised. This is to show that PassivBIM correctly evaluated the absolute heat demand when it dealt with two identical houses in one IFC file. It also proves that the TFA was correctly calculated for the IFC file with two houses, as the heat demand normalised by the TFA is the same for one and for two (identical) houses in one IFC file. 


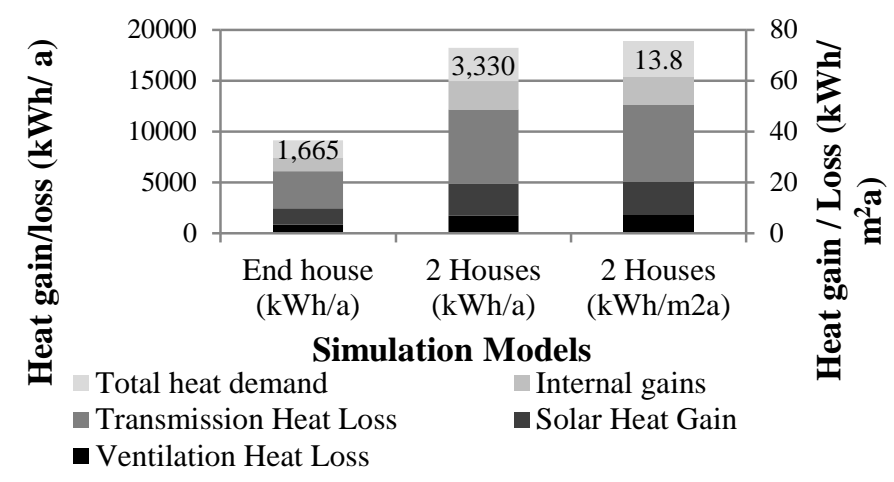

Figure 13 Heat transfer in Hannover buildings

\subsection{Validation Study 2 -Larch House, Wales}

Overall, the calculated Larch House heat demand is closer to published figures than the Hannover Kronsberg buildings. The heat losses and gains between (a) a model with all data imported from PHPP and (b) the same model overwritten with geometry from an IFC file are shown in Figure 14. These models use the Ebbw Vale climate file.

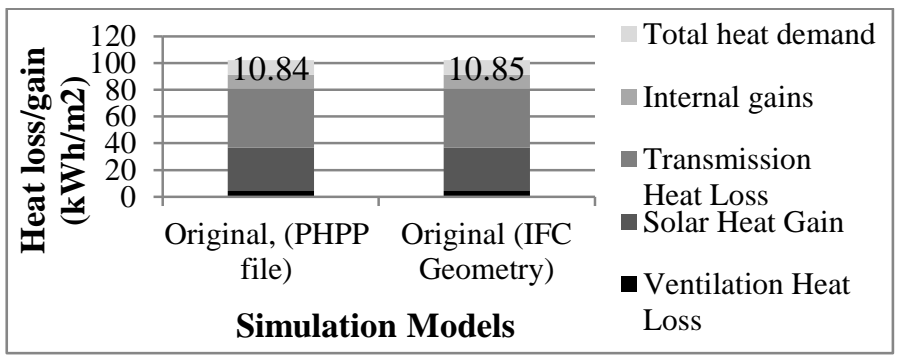

\section{Figure 14 Heat transfer of Larch house with and without IFC geometry}

The percentage difference in total heat demand in Figure 14 is only $0.1 \%$, which further validates the PassivBIM geometry extraction process. The heat demand for the Larch house in the Ebbw Vale climate is lower than in the study by McLeod et al. [19]. This could be due to the original PHPP07 having two methods (annual and monthly) for working out the annual heat demand.

When planning a building for whole life optimization and resilience, it may be useful to investigate how it could behave in a future climate or in an urban heat island. The effects of these two scenarios are presented in Figure 15.

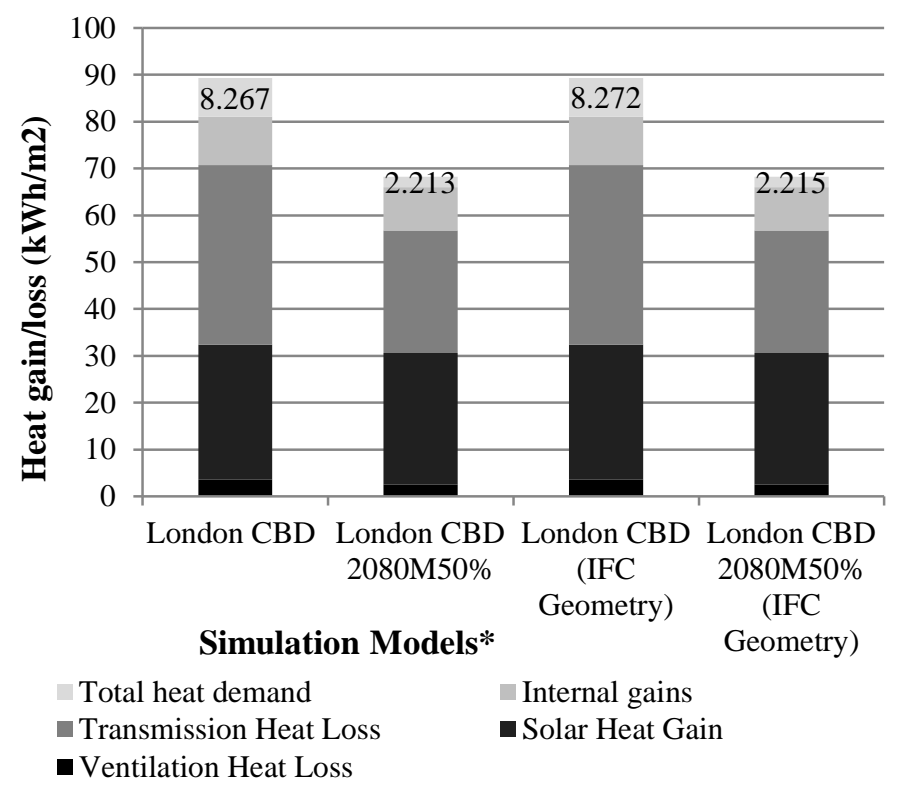

*Footnote: The results are shown to three decimal places in order to show the magnitude of the small discrepancy between PHPP and PassivBIM calculations. 
The 'London CBD' and 'London CBD 2080M50\%' models use only data extracted from PHPP. They are the basis of '(IFC Geometry)' models, wherein the geometry is overwritten. The percentage difference between the PassivBIM and published [19] 'London CBD' and 'London CBD2080M50\%' models is 4.3\% and 3.9\% respectively. The climate files are the same as used in the report, so any error is associated with discrepancies in the PHPP models. It could also be due to different methods in calculating the annual heat demand. More importantly, in relation to this study, the difference between models with and without IFC geometry is low. The percentage difference between the 'London CBD' and 'London CBD 2080M50\%' with and without IFC geometry is $0.06 \%$ and $0.07 \%$ respectively. This is another validation of the PassivBIM geometry extraction process. Additionally, as a consequence of the 'IfcDesignAlternative' entity, a single IFC model can now hold multiple sets of results as shown in Figure 16 and Figure 18.

Further processing can now be performed on the models to inform design decisions. As the heat demand is a quasi-steady state calculation, it can be reversed and used to calculate upper limits for the performance specification of individual building elements. Only one intervention is currently considered at one time, so one output value is limited and one input parameter is recalculated. For example, Table 3 shows a scenario where the annual heat demand has been set to the Passivhaus limiting threshold of $15 \mathrm{kWh} / \mathrm{m}^{2} \mathrm{a}$, and for the London 2080 model (by reversing the heat demand equations) the optimum exterior wall area has been calculated as approximately $440 \mathrm{~m}^{2}$. This shows that even if the envelope size was roughly doubled, in the future the building would still have an acceptable energy demand as a Passivhaus.

Table 3 Building elements characteristics before and upper limit of tolerance after annual heat demand is limited to $15 \mathrm{kWh} / \mathrm{m}^{2}$ a for the Larch House (assuming a $2080 \mathrm{M} 50^{\text {th }}$ percentile scenario).

\begin{tabular}{|l|l|l|l|}
\hline $\begin{array}{l}\text { Building } \\
\text { element }\end{array}$ & $\begin{array}{l}\text { Characterist } \\
\text { ic }\end{array}$ & $\begin{array}{l}\text { Original } \\
\text { value }\end{array}$ & $\begin{array}{l}\text { Calculated } \\
\text { after } \\
\text { limitation }\end{array}$ \\
\hline $\begin{array}{l}\text { Exterior Wall - } \\
\text { Ambient }\end{array}$ & area $\left(\mathrm{m}^{2}\right)$ & 176.629 & 440.516 \\
\hline $\begin{array}{l}\text { Exterior Wall - } \\
\text { Ambient }\end{array}$ & $\begin{array}{l}\mathrm{u}-\text { value } \\
\left(\mathrm{W} / \mathrm{m}^{2} \mathrm{~K}\right)\end{array}$ & 0.095 & 0.237 \\
\hline $\begin{array}{l}\text { Windows } \\
\text { (South) }\end{array}$ & g-value & 0.597 & 0.886 \\
\hline $\begin{array}{l}\text { Windows } \\
\text { (South) }\end{array}$ & area $\left(\mathrm{m}^{2}\right)$ & 28.074 & is 41.647 \\
\hline Windows(all) & area $\left(\mathrm{m}^{2}\right)$ & 36.531 & 69.454 \\
\hline Windows(all) & $\begin{array}{l}\mathrm{u}-\mathrm{value} \\
\left(\mathrm{W} / \mathrm{m}^{2} \mathrm{~K}\right)\end{array}$ & 0.762 & 1.448 \\
\hline Windows(all) & g- value & 0.527 & 1.395 \\
\hline
\end{tabular}

This data could be used to test a buildings resiliency to climate change and thereby assess whole life performance. For example, the data shows the building is resilient to climate change and will still perform to the Passivhaus standard in 2080 (under an IPCC Medium emissions scenario) as:

- $\quad$ The U-values do not have to be as low in the future as they are currently. This means the current building elements will deliver an even lower heating demand under a future climate.

- The area of south oriented windows could theoretically be increased by up to $40 \%$ and the heat demand would still be below $15 \mathrm{kWh} / \mathrm{m}^{2}$ a under a future climate. Although there may be other consequential effects associated with this decision such as increased overheating risks, as noted by McLeod et al [16].

It must be kept in mind that some of the results may not make technical sense, for example in Table 3 the g-value is calculated as 1.395, which implies a solar heat gain coefficient greater than unity. Some characteristic value limits need to be introduced to this calculation, and it needs to be extended to enable multiple interventions to be made and an optimised answer to be given. In addition, the algorithm used could be extended to calculate the peak load as this could provide more interesting performance insights than simply considering the overall heating demand.

In addition, PassivBIM can be used to inform rapid prototyping design decisions, as discussed in Section 9.

\section{EXTENDED CONCEPTS}


The initial research presented in this paper has focused on demonstrating the validation of PassivBIM as a tool for automating the extraction of geometric data from an IFC file and combining it with data from an energy simulation tool (PHPP). In addition to automating this core process the creation of a Java based energy domain opens up the possibility for rapid design optimisation routines and this capability offers significant potential for future work. At a very basic level, for example, if a building was not achieving the target $15 \mathrm{kWh} / \mathrm{m}^{2}$ a, its performance could be limited to the certification target level using the PassivBIM tool. The designer could then check which parameters would have to be changed and to what extent (and at what additional build cost) in order to achieve the target. Currently the development of this application is relatively simple and as a result has some limitations. For example increasing the window area will also affect the opaque transmission losses and gains. Its aim is to show that once the geometrical data is in a PHPP friendly format and is coupled directly to energy calculations, design decisions can be better informed. By way of illustrating this potential, a simple master planning optimisation exercise is described below, based on the Hannover Kronsberg project (Section 6).

By using specific heat demand data from an end house and middle house in a terrace row it is possible to calculate the mean heating demand resulting from different layouts (and orientations) of terraced buildings. Figure 16 is an example of terraces created using the Hannover Kronsberg models. It shows that the overall energetic effectiveness of terracing houses tails off at around 6 houses. This is useful information to a designer who is considering using terraced houses and or semi-detached buildings as a means to improve the overall energy efficiency or minimise the thermal specification/ capex spend on a given site.

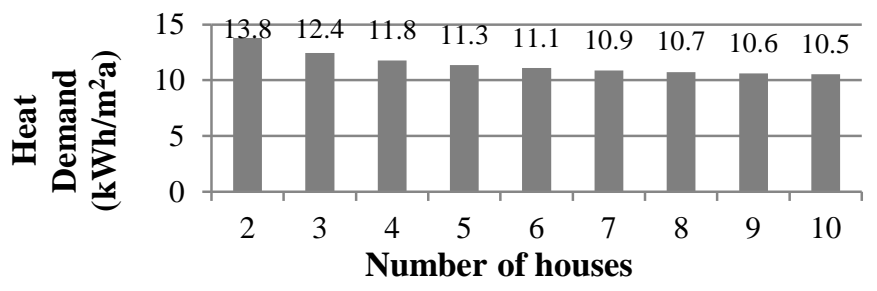

Figure 16 Annual heat demand in terraces

Furthermore, this function can be applied to test various configurations of terraced buildings. Figure 17 shows example configurations of terraced and semi-detached dwellings. Figure 17 (a) shows four terraces, where one-half is composed of two buildings (semis) and the other are composed of three buildings. In Figure 17 (b) there are just two terraces, and each has five dwellings. Figure 17 (c) contains 4 terraces, each comprising of 2 dwellings (semis). Figure 18 shows the heat demand of these buildings, where parts (a), (b) and (c) correspond to the terraces illustrated in Figure 17. The dotted line in Figure 18(c) signifies the official Passivhaus annual heating demand upper limit, $15 \mathrm{kWh} / \mathrm{m}^{2}$. This analysis function could be further extended to (1) accept more model variations, so the terraces in a building could have different layouts, and (2) calculate the compounding effect of the site shading occurring from other buildings. The results show that scenario (b) gives the lowest average energy consumption, although it could be argued it is not the most aesthetically pleasing solution. Scenario (c) shows how the orientation of a building substantially affects heating demand. It is important to note that in Figure 18 (c), the ranking of the orientations from best to worst in terms of energy efficiency are: South, North, then East and West have joint third place. This unusual result is due to the fact the building used has large windows on the South facade, smaller windows on the North side, and no windows on the East and West side. Whilst this means the result is context specific, but it does underline the importance of window ratios and orientation in relation to energy efficiency. 

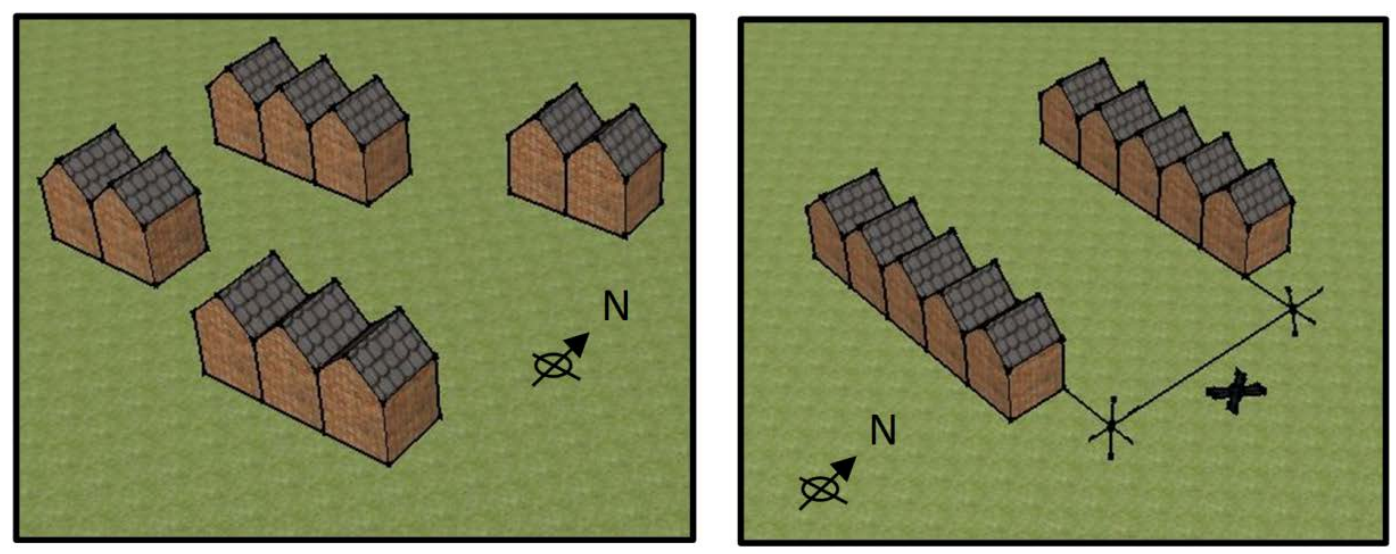

(a)

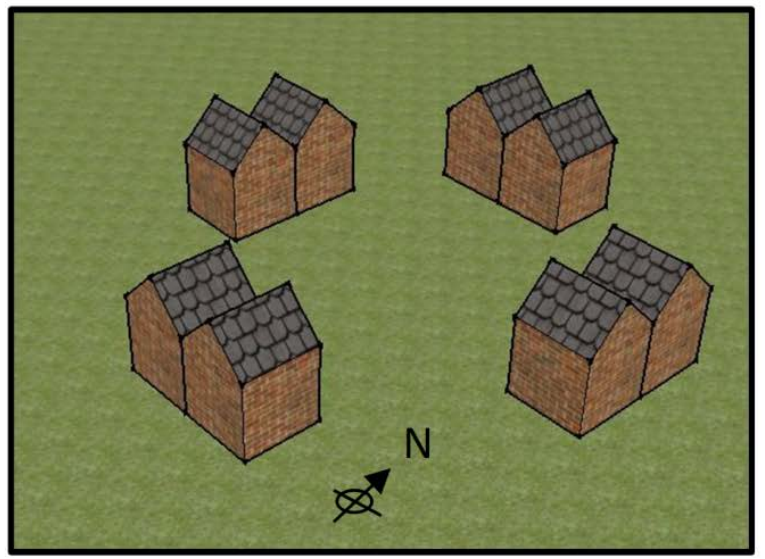

(b)*

(c)

*Footnote: The distance ' $x$ ' in Figure 17(b) could cause buildings to cast shade on each other, especially in the winter. This is not taken into consideration, as the 'shading' component of PHPP has not yet been implemented in PassivBIM.

Figure 17 Three scenarios (a), (b) and (c) show possible configurations of 10 terraced buildings

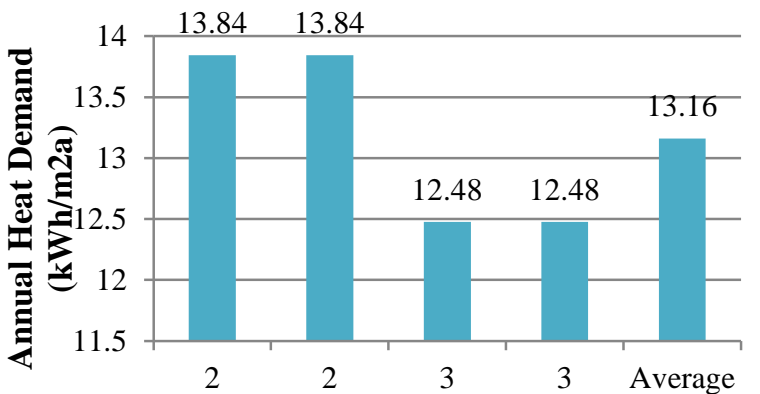

Number of houses

(a)

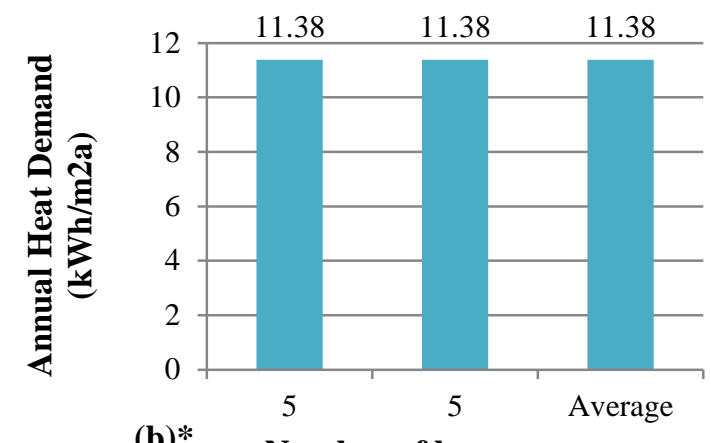

(b)* Number of houses

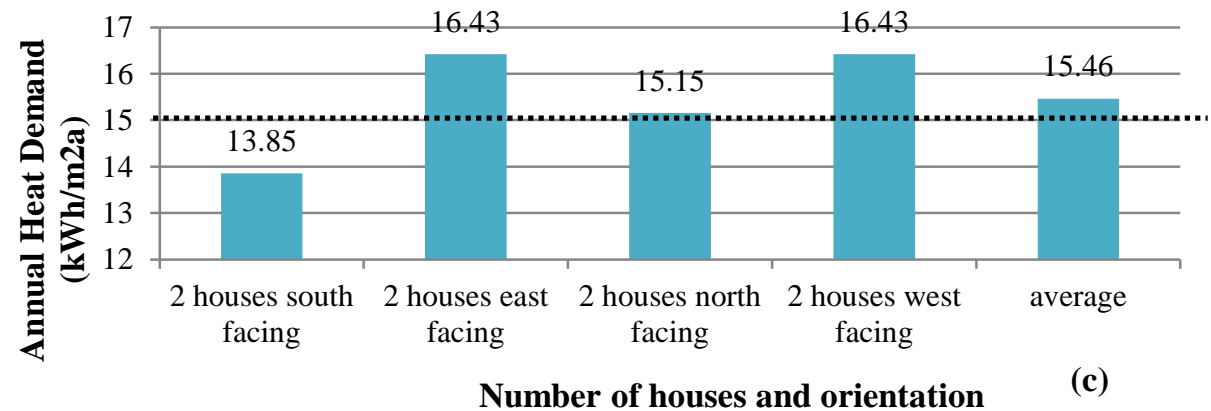

Figure 18 Mean Annual Specific Heat Demand of terraced buildings in configurations (a), (b) and (c).

Beyond the initial concepts highlighted above PassivBIM could be readily extended to provide more complex optimization functions, such as the form optimiser proposed by Granadeiro et al. [59]. 


\section{CONCLUSION}

This study describes an implementation of a methodology that extends the IFC schema with energy concepts. The resulting PassivBIM system can read both IFC and PHPP files and calculate the annual heat demand. It can also export data back into PHPP, which is one of the main advantages of PassivBIM, since only the PHPP tool can be used currently for the official certification of a Passivhaus. The extended schema allows both descriptive and behavioural data to be stored in the same place. This approach supports the concept of inter-disciplinary collaboration, as the data can be readily shared between project team members in order to expedite consensual design decisions. The paper also includes some preliminary examples of how the data could be used to inform design decisions, in relation to master planning and creating sustainable 'future proofed' buildings.

The process of extracting and processing geometry has been described, and then validated with two case studies. The case studies involved both detached and terraced buildings, and ones which utilised the space under the roof differently (i.e. warm and cold roof constructions). The error between a model using only PHPP data and one with IFC geometry remains below $0.1 \%$ for the Larch House models, and 2.9\% for the more complex Hannover Kronsberg models. When this geometry is used to calculate the final annual heat demand for the Larch House case study with future weather files [19], results differ to the published data by up to $4 \%$. This discrepancy is mainly attributed to the difference in initial building models and not the geometry extraction. In summary the process of automating data entry for PHPP shows good potential, and supports the aim of creating interoperable software to facilitate the design of sustainable buildings.

\section{LIMITATIONS AND FUTURE WORK}

One of the main limitations of the work is that the case studies use relatively simple geometry, and have only been tested using Revit. As a result, future work is needed to validate the tool with a wider range of models, which would include more complex (sloping and curved) wall and roof geometry. Different BIM tools should be used to generate the IFC files used in the case studies, in order to verify that the assumptions made with respect to the extraction of geometry are valid for files generated by other tools. If they are not, this could imply a consistency issue that needs to be addressed by further development of the IFC schema. In terms of the functional limitations of the PassivBIM tool itself, further sensitivity analysis and optimisation capabilities could be added. Currently these functions are limited and characteristic value limits need to be manually applied when constrained outputs are used to back-calculate input parameter thresholds. The optimization calculation routines need to be extended to enable multivariate optimization and master planning utilities. These could include functions ranging in simplicity from a shading optimisation functions to a combined multi parametric/multivariate and transient time series optimisation against pre-selected data. An IFC exportation ability could also be developed, which would send files to an online database. This would support collaboration between different project stakeholders. The development of a user-friendly interface needs to be addressed. Finally, the energy analysis extension could be used to develop an 'Architectural Design to Passivhaus' MVD in order to limit the introduction of errors caused by inconsistent IFC file generation. This could use an existing MVD as its basis, in order to profit from an established framework, which has already been extensively reviewed by a team of experts.

\section{ACKNOWLEDGEMENT}

The authors would like to thank 'bere:architects' for access to the Larch House building data. They would also like to thank the 'Building Research Establishment' and 'EPSRC' for funding the PhD of the corrosponding author.

\section{REFERENCES}

[1] G. J. Jenkins, J. M. Murphy, D. M. H. Sexton, J. A. Lowe, P. Jones, and C. G. Kilsby, 'UK Climate Projections: Briefing Report', Met Office Hadley Centre, Exeter, UK, 2009.

[2] WBCSD, 'Transforming the Market: Energy Efficiency in Buildings', World Business Council for Sustainable Development, 2013. [Online]. Available: http://www.wbcsd.org/transformingthemarketeeb.aspx. [Accessed: 15-Jun-2013].

[3] UK Parliament, 'Climate Change Act 2008', The Stationary Office Limited, 2008.

[4] R. S. McLeod, C. J. Hopfe, and Y. Rezgui, 'An investigation into recent proposals for a revised definition of zero carbon homes in the UK', Energy Policy, vol. 46, pp. 25-35, Jul. 2012.

[5] P. King and M. Clare, 'The Definition of Zero Carbon. Zero Carbon Task Group Report', UK Green Building Council, 2008.

[6] The European Parliament and The Council of the European Union, 'Directive 2010/31/EU of the European Parliament and of the Council of 19 May 2010 on the energy performance of buildings’, Official Journal of the European Union, vol. 53, no. L 153, Jun. 2010.

[7] Cabinet Office, 'Government Construction Strategy’, May 2011. 
[8] L. H. Forbes and S. M. Ahmed, Modern Construction: Lean Project Delivery and Integrated Practices. Boca Raton, FL: CRC Press, 2011.

[9] D. Bryde, M. Broquetas, and J. M. Volm, 'The project benefits of Building Information Modelling (BIM)', International Journal of Project Management, vol. In Press, 2013.

[10] W. Keiholz, B. Ferries, F. Andrieux, and J. Noel, 'A Simple, neutral building data model', in eWork and eBusiness in Architecture, Engineering and construction, 2009.

[11] W. Feist, 'The Passive House Institute’, 2012. [Online]. Available: http://www.passiv.de/en/index.php. [Accessed: 07-Feb2013].

[12] R.S. McLeod, 2014. [Online]. An Investigation into the Performance of Low Energy and Zero Carbon Buildings in a Changing Climate. Available: http://orca.cf.ac.uk/56966/1/2014McLeodRPhD.pdf [Accessed: 11-Dec-2014].

[13] iPHA, ‘Map of Certified Passive House Buildings’, International Passive House Association, 2013. [Online]. Available: http://www.passivehouse-international.org/index.php?page_id=288. [Accessed: 20-Jun-2013].

[14] Zero Carbon Hub Task Group, 'Defining a Fabric Energy Efficiency Standard for Zero Carbon Homes: Task Group Recommendations November 2009’. Nov-2009.

[15] W. Feist, 'PHPP: Far More Than Just An Energy Calculation Tool', PHPP: Far more than just an energy calculation tool, 2007. [Online]. Available: http://www.passivhaustagung.de/Passive_House_E/PHPP.html. [Accessed: 03-Nov-2011].

[16] R. S. McLeod, C. J. Hopfe, and A. Kwan, 'An investigation into future performance and overheating risks in Passivhaus dwellings’, Building and Environment, vol. 70, pp. 189-209, Dec. 2013.

[17] J. Schnieders and A. Hermelink, 'CEPHEUS results: measurements and occupants' satisfaction provide evidence for Passive Houses being an option for sustainable building’, Energy Policy, vol. 34, no. 2, pp. 151-171, 2006.

[18] W. Feist, R. Pfluger, B. Kaufmann, J. Schnieders, and O. Kah, 'Passive House Planning Package 2007’, Passive House Institute Darmstadt, 2007.

[19] R. S. McLeod, C. J. Hopfe, and Y. Rezgui, 'A proposed method for generating high resolution current and future climate data for Passivhaus design’, Energy and Buildings, vol. 55, pp. 481-493, 2012.

[20] 'Take a Tour | designPH’. [Online]. Available: http://www.designph.org/product. [Accessed: 13-Jun-2014].

[21] 'ph-tool'. [Online]. Available: http://ph-tool.com/. [Accessed: 13-Jun-2014].

[22] G. Duncan, 'Revit and PHPP: Getting BIM and Energy Modeling Software to Work Together', 2011. .

[23] DesignReform, 'Green Fund Passivhaus Series 01 - Intro to PH in Revit', 2011. [Online]. Available: http://designreform.net/learning/2011/10/26/green-fund-passivhaus-series-01-intro-ph-revit-0. [Accessed: 17-Jan-2013].

[24] M. Pickering, ‘BIM Energy Analysis with ArchiCAD 16’, 2012.

[25] buildingSMART, 'Industry Foundation Classes (IFC)', 2013. [Online]. Available: http://buildingsmart.com/standards/ifc. [Accessed: 18-Apr-2012].

[26] J. O’Donnell, R. See, C. Rose, T. Maile, V. Bazjanac, and P. Haves, 'SimModel: A domain data model for whole building energy simulation’, in Proceedings of Building Simulation 2011, 2011, pp. 382-389.

[27] C. M. Rose and V. Bazjanac, ‘An algorithm to generate space boundaries for building energy simulation’, Engineering with Computers, 2013.

[28] A. Cemesova, C. J. Hopfe, and Y. Rezgui, 'An approach to facilitating data exchange between BIM environments and a low energy design tool', in Proceedings of BS2013: 13th Conference of International Building Performance Simulation Association, Chambery, France, 2013, pp. 3234-3241. 
[29] A. Gupta, A. Cemesova, C. J. Hopfe, Y. Rezgui, and T. Sweet, 'A conceptual framework to support solar PV simulation using an open-BIM data exchange standard', Automation in Construction, vol. 37, pp. 166-181, 2014.

[30] W. Feist, O. Kah, Peper, Soren, and M. von Oesen, 'PEP Project Information No. 1: Climate Neutral Passive House Estate in Hannover- Kronsberg: Construction and Measurement Results’. European Commission, 2003.

[31] Autodesk, Inc., 'Autodesk Revit Products', Autodesk, 2013. [Online]. Available: http://www.autodesk.co.uk/adsk/servlet/pc/index?siteID=452932\&id=14645193. [Accessed: 30-Jan-2013].

[32] R. See, P. Haves, P. Sreekanthan, J. O’Donnell, M. Basarkar, and K. Settlemyre, 'Development of a user interface for the EnergyPlus whole building energy simulation program', in Building Simulation 2011: 12th Conference of International Building Performance Association, Sydney, 2011, pp. 2919-2926.

[33] V. Bazjanac and A. Kiviniemi, 'Reduction, simplification, translation and interpretation in the exchange of model data', in Proceedings of the 24th CIB W78 conference, Maribor, 2007, vol. 78, pp. 163-168.

[34] C. Wilkins and A. Kiviniemi, 'Engineering-Centric BIM’, ASHRAE Journal, pp. 44-48, 2008.

[35] C. Eastman, 'Building Product models: Computer Environments Supporting Design and Construction’, CRC Press, 1999.

[36] E. Krygiel and B. Nies, Green BIM. Indianapolis, Indiana: Wiley Publishing, Inc, 2008.

[37] A. Osello, G. Cangialosi, D. Dalmasso, A. Di Paolo, M. L. Turco, P. Piumatti, and M. Vozzola, 'Architecture data and energy efficiency simulations: BIM and interoperability standards’, in Proceedings of Building Simulation 2011, Sydney, 2011, pp. 1521-1526.

[38] H. J. Moon, M. S. Choi, S. K. Kim, and S. H. Ryu, 'Case studies for the evaluation of interoperability between a BIM based architectural model and building performance analysis programs', in Proceedings of 12th Conference of International Building Performance Simulation Association, 2011, pp. 1521-1526.

[39] C. Eastman, P. Teicholz, R. Sacks, and K. Liston, BIM Handbook: A Guide to Building Information Modelling for Owners, Managers, Designers, Engineers, and Contractors. Canada: John Wiley \& Sons. Inc., 2011.

[40] A. Cormier, S. Robert, P. Roger, L. Stephan, and E. Wurtz, 'Towards a BIM-based service oriented platform: application to building energy performance simulation’, in Proceedings of Building Simulation 2011, Sydney, 2011.

[41] T. Maile, M. Fischer, and V. Bazjanac, 'Building Energy Performance Simulation Tools - a Life-Cycle and Interoperable Perspective’, in CIFE Working Paper \#WP107, 2007.

[42] R. J. Hitchcock and J. Wong, 'Transforming IFC architectural view BIMS for energy simulation', in Proceedings of Building Simulation 2011, Sydney, 2011, pp. 1089-1095.

[43] G. Augenbroe, 'Integrated building performance evaluation in early design stages', Building and Environment, vol. 27, pp. 149-161, 1992.

[44] J. T. O’Donnell, T. Maile, C. Rose, N. Mrazovic, E. Morrissey, C. Regnier, K. Parrish, and V. Bazjanac, 'Transforming BIM to BEM: Generation of Building Geometry for the NASA Ames Sustainability Base BIM', Lawrence Berkeley National Laboratory, Berkeley, CA, Jan. 2013.

[45] Youngjib Ham and Mani Golparvar-Fard, 'Mapping actual thermal properties to building elements in gbXML-based BIM for reliable building energy performance modeling', Automation in Construction, vol. 49, no. Part B, pp. 214-224, 2015.

[46] R. Hetherington, R. Laney, S. Peake, and D. Oldham, 'Integrated building design, information and simulation modelling: the need for a new hierarchy’, in Proceedings of Building Simulation 2011, Sydney, 2011.

[47] W. Feist, R. Pfluger, J. Schnieders, and O. Kah, B. Kaufmann, B. Krick, Z. Bastian, and W. Ebbel, 'Passive House Planning Package (PHPP) Version 8 (2013)’. PHI, Jul-2013.

[48] C. J. Hopfe and R. S. McLeod, 'Passivhaus TFA - Dwellings’, PassivHausUK, 2010.

[49] BLIS Consortium and Digital Alchemy, 'IFC Solutions Factory’, 2012. [Online]. Available: http://www.blisproject.org/IAI-MVD/. [Accessed: 10-Sep-2013]. 
[50] J. D. Foley, A. van Dam, S. K. Feiner, and J. F. Hughes, Computer Graphics: Principles and Practise, Second Edition. Reading, Massachusetts: Addison-Wesley Publishing Company, Inc., 1996.

[51] Wawan Solihin, 'Modeling for IFC with AutoCAD Architecture’, Autodesk, 2010.

[52] Y. Rezgui, A. Cemesova, and C. J. Hopfe, 'Building Systems Modeling and Design Challenges', Encyclopedia of Life Support Systems. UNESCO, 2010.

[53] A. Cemesova, 'Enhancing BIM-based data transfer to support the design of low energy buildings', Cardiff University, 2013.

[54] Open IFC Tools, ‘Open IFC Tools’, 2012. [Online]. Available: http://www.openifctools.org/. [Accessed: 18-Apr-2012].

[55] Apache POI, 'Apache POI - the Java API for Microsoft Documents’, 2012. [Online]. Available: http://poi.apache.org/. [Accessed: 29-May-2013].

[56] W. Feist, S. Peper, and M. von Oesen, 'CEPHEUS Projektdokumentation Nr. 18’, PassivHaus Institut, $18,2001$.

[57] M. S. Sodha, N. K. Bansal, A. K. Bansal, and M. A. S. Malik, Solar passive building science and design. Oxford: Pergamon Press, 1986.

[58] iPHA, 'Passivhaus Building Database', 2012. [Online]. Available: http://www.passivhausprojekte.de/projekte.php?detail=1849\&keyword=Larch\%20House2012. [Accessed: 29-Jan-2013].

[59] V. Granadeiro, J. P. Duarte, J. R. Correia, and V. M. S. Leal, 'Building envelope shape design in early stages of the design process: Integrating architectural design systems and energy simulation’, Automation in Construction, vol. 32, pp. 196-209, 2013. 